\title{
MATERIAŁ KOSTNY Z CZTERECH GROBÓW KULTURY STRZYŻOWSKIEJ WYEKSPLOROWANYCH W LATACH 2015-2016 NA STANOWISKU 15 W ROGALINIE W ŚWIETLE BADAŃ INTERDYSCYPLINARNYCH*
}

\author{
HUMAN SKELETAL REMAINS FROM FOUR GRAVES \\ OF STRZYŻÓW CULTURE EXCAVATED IN 2015-2016 AT SITE 15 \\ IN ROGALIN, POLAND STUDIED IN INTERDISCIPLINARY RESEARCH
}

\begin{abstract}
In 2008 a burial site was discovered in Rogalin (eastern Poland). Interdisciplinary investigations were carried out and it was concluded that the site was a unique example of Strzyżów culture, an agricultural culture found in eastern Poland and western Ukraine, dated to the Early Bronze Age (2000/1950-1600 BC). Strzyżów culture spread over the area from the eastern part of Lublin Upland (area between the upper Wieprz river and Bug river) to the area of south-western Volhynia crossing Horyn river in present-day Ukraine. The highest density of its sites is in the territory of Horodło Plateau and near the town of Hrubieszów. Sixteen graves were discovered between 2009 and 2016. The aim of the study was to conduct analysis of skeletal remains from four burial graves - no. 13, 14, 15, and 16 excavated in 2015 and 2016. Research was based on macroscopic, stereomicroscopic analysis, X-ray and CT examinations.
\end{abstract}

KEY WORDS: archaeology, Early Bronze Age, Strzyżów culture, anthropology, odontology, computer tomography, musculoskeletal stress markers (MSM), enthesis

\section{WSTĘP}

Kultura strzyżowska powstała około $2000 \mathrm{BC}$ na bazie tradycji post-sznurowych oraz pod wpływem

* Artykuł prezentuje wyniki badań przeprowadzonych w ramach projektu „Najmniej znany spośród najbardziej interesujących - obrządek pogrzebowy kultury strzyżowskiej" sfinansowanego ze środków Narodowego Centrum Nauki przyznanych na podstawie decyzji numer 2015/17/ HS3/02865. wschodnich ugrupowań. Rozwijała się równolegle do kultury mierzanowickiej do około 1600 BC, kiedy ustąpiła miejsca kulturze trzcinieckiej. Zasięgiem obejmowała tereny od wschodniej części Wyżyny Lubelskiej, tj. obszar między górnym Wieprzem a Bugiem, po terytorium południowo-zachodniego Wołynia, sięgając po rzekę Horyń na terenie dzisiejszej Ukrainy. Największe zagęszczenie jej stanowisk znajduje się na terytorium Grzędy Horodelskiej oraz w okolicach Hrubieszowa.

Cmentarzyska tej społeczności lokowane były przeważnie na południowych stokach wzniesień, 
gdzie jamy grobowe usytuowane były głównie na osi wschód-zachód. W grobie składano zmarłego w pozycji wyprostowanej na plecach. Część z odnalezionych szkieletów nosi ślady nadpalenia.

Stanowisko nr 15 w Rogalinie odkryto w 2008 roku. Od roku 2009 prowadzone są tam ratownicze badania archeologiczne. Cmentarzysko kultury strzyżowskiej położone jest na terenie intensywnie wykorzystywanym rolniczo, przez co stale narażone jest na degradację. W latach 2009-2016 odkryto 16 grobów i wyeksplorowano szczątki kostne 19 osobników. Groby nr 1-12 zostały opublikowane w 2015 roku (Abreu-Głowacka 2015, 170-181; Glapiński et al. 2015, 154-162; Hyrchała 2015, 52-79; Kociemba 2015, 124-129; Lorkiewicz-Muszyńska et al. 2015, 130-139; Lorkiewicz-Muszyńska 2015, 140-145; Przystańska et al. 2015, 162-167) oraz w 2017 (Przystańska et al. 2017). Przedmiotem badań były kolejne pochówki przebadane w latach 2015-2016 (groby nr 13-16). $\mathrm{Z}$ uwagi na fakt, że stanowisko znajduje się na polu ornym, stan zachowania obiektów jest bardzo zróżnicowany. Część z nich odkryta została tuż pod powierzchnią oraniny z wyraźnymi śladami zniszczeń dokonanych przez maszyny rolnicze. Pochówki, których strop znajdował się bezpośrednio pod warstwą oraniny i ze szkieletami na głębokości $35-40 \mathrm{~cm}$ od obecnej powierzchni gruntu, były dobrze zachowane.

Badania archeologiczne uzupełniono szeregiem analiz specjalistycznych. Materiały poddano analizom anatomo-morfologicznym oraz kompleksowym interdyscyplinarnym badaniom z zakresu antropologii, odontologii, genetyki i radiologii.

Prowadzone w sposób interdyscyplinarny badania ludzkich szczątków kostnych eksplorowanych na stanowiskach archeologicznych dostarczają szeregu ważnych informacji o dawnych populacjach ludzkich. Wykorzystanie metod makroskopowych, mikroskopowych i radiologicznych w badaniach ludzkich szczątków kostnych pozwala na przeprowadzenie analiz w szerokim zakresie, zarówno na poziomie osobniczym, jak i populacyjnym.

\section{MATERIAŁ I METODY}

Interdyscyplinarnym badaniom poddano szczątki kostne wyeksplorowane w latach 2015-2016 z czterech grobów nr 13, 14, 15 i 16 na stan. 15 w Rogalinie (aspekt archeologiczny tych grobów został szeroko omówiony w artykule A. Hyrchały, w tym tomie). W przypadku szczątków wyeksplorowanych z grobów nr 13 i 14 stwierdzono występowanie fragmentów czaszek i elementów szkieletów pozaczaszkowych. Materiały z grobów nr 14 i 16 wykazywały cechy przepalenia. Szkielet wyeksplorowany z grobu nr 15 był w dobrym stanie zachowania.

Badania szczątków kostnych przeprowadzono z wykorzystaniem metod makroskopowych, mikroskopowych, radiologicznych i DNA. Materiały poddane zostały analizie anatomo-morfologicznej oraz analizie antropologicznej. W opracowaniu szkieletów wykorzystano ogólnie przyjęte metody analizy antropologicznej i opisy anatomiczne kośćca (Ubelaker 1978; Bochenek, Reicher 1990; Buikstra, Ubelaker 1994).

Zarówno w opisie czaszek, jak i szkieletów pozaczaszkowych, uwzględniono informacje dotyczące stanu ich zachowania, cechy budowy kości, stopień zaawansowania kostnienia, stopień mineralizacji zębów, ewentualne zmiany patologiczne oraz wykonano pomiary cech metrycznych.

W celu określenia płci ocenie poddano cechy dymorficzne, przede wszystkim $\mathrm{w}$ zakresie morfologii miednicy i czaszki oraz kości długich (Acsadi, Nemeskeri 1970; Malinowski, Wolański 1988; Buikstra, Ubelaker 1994; White, Folkens 2005). Analizie poddano ponadto masywność i stopień ukształtowania rzeźby przyczepów mięśniowych. W przypadku szkieletów dziecięcych płeć określano przy wykorzystaniu metod DNA.

W celu oszacowania wieku biologicznego osobników w chwili zgonu uwzględniono kryterium wieku kostnego, wieku morfologicznego i kryterium wieku zębowego. Analizowano stopień obliteracji szwów czaszkowych (endokranialnie i egzokranialnie), stan końców bliższych kości ramiennej i kości udowej w oparciu o wykonane zdjęcia rentgenowskie, powierzchnie spojenia łonowego i powierzchnie uchowate (Acsadi, Nemeskeri 1970; Buikstra, Ubelaker 1994; Malinowski, Wolański 1988; Lovejoy 1985a; Todd 1920). Uwzględniono także nasilenie zmian inwolucyjnych kośćca. Na podstawie badań makroskopowych oraz obserwacji w mikroskopie stereoskopowym oceniano także starcie zębów (Smith, Knight 1984). Analiza szczątków osobników dziecięcych obejmowała analizy formowania się uzębienia mlecznego i stałego, czy wielkości kości długich (Haavikko 1970; Buikstra, Ubelaker 1994).

Przy ocenie wieku osobników uwzględniono standardowe kategorie: infans I - wczesne dzieciństwo (od urodzenia do 6-7 roku życia), infans II - późne dzieciństwo (od 6-7 do 12-14 r. ż.), juvenis - wiek 
młodzieńczy (od 12-14 do 20-22 r. ż.), adultus - wiek dorosły (od 20-22 do 30-35 r. ż.), maturus - wiek dojrzały (od 30-35 do 50-55 r. ż.), senilis - wiek starczy (powyżej 55 r. ż.) (Malinowski, Strzałko 1985; Malinowski, Wolański 1988; Buikstra, Ubelaker 1994).

Pomiary cech metrycznych zostały wykonane zgodnie z zasadami techniki martinowskiej (Martin, Saller 1957). Rekonstrukcji przyżyciowej wysokości ciała dokonano w przypadku osobnika z grobu nr 15 w oparciu o pomiary największej długości kości ramiennej, promieniowej, łokciowej, udowej i piszczelowej (Trotter, Gleser 1952). Szacowanie masy ciała (osobnik z grobu nr 15) przeprowadzono na podstawie pomiarów głowy kości udowej (Ruff et al. 1991; Grine et al. 1995; Auerbach, Ruff 2004).

$\mathrm{W}$ analizie uzębienia uwzględniono numerację zębów według obowiązującego w Polsce Systemu Międzynarodowego FDI, w którym każdemu zębowi przyporządkowane jest odpowiednie dwucyfrowe oznaczenie (Turp, Kurt 1995; Glapiński et al. 2015).

W celu oceny stanu zdrowia dokonano oceny zmian patologicznych, przypadków długotrwałych schorzeń, dających obraz w układzie kostnym oraz wad rozwojowych. W badaniach stanu zdrowia i oceny aktywności fizycznej za życia dokonano oceny wyznaczników stresu mięśniowo-szkieletowego (MSM - musculoskeletal stress markers) (Hawkey, Merbs 1995; Hawkey 1998; Peterson 1998; Mariotti et al. 2007; Myszka 2007; Iwanek et al. 2010; Foster et al. 2012; Berthom et al. 2018; Khudaverdyan et al. 2018).

W celu poszerzenia analiz makroskopowych wykonano zdjęcia rentgenowskie i tomografię komputerową (KT) wybranych elementów kostnych. W tym celu wykorzystano mobilny aparat rentgenowski DX-D-100 oraz tomograf komputerowy Simens Somatom. Dokonano dodatkowo analizy zatok czołowych, jak również wymiarowania na obrazach cyfrowych rtg. Analizę zdjęć rentgenowskich w wersji cyfrowej przeprowadzono z wykorzystaniem programu SE Media Viewer wersja 4.0.2.0. Użyto dostępnego w oprogramowaniu narzędzia umożliwiającego wymiarowanie (z dokładnością do $0,1 \mathrm{~cm}$ ), z jego pomocą dokonano pomiarów analizowanych struktur. Analizie poddano także cechy indywidualne uzębienia $\mathrm{w}$ aspekcie ich zróżnicowania morfologicznego i ewentualnych zmian chorobowych niewidocznych makroskopowo.

Przeprowadzono dodatkowo analizy z wykorzystaniem mikroskopu stereoskopowego. Wybrane ele- menty poddano obserwacji makroskopowej oraz mikroskopowej w mikroskopie stereoskopowym Olympus SZ.

Izolację DNA dokonano metodą kolumienkową za pomocą zestawu GeneMatrix Bone Purification Kit, Firmy EURx Ltd.

Pomiar stężenia DNA dokonano za pomocą real-time PCR Rotor Gene-Q firmy Qiagen z użyciem multipleksu Investigator Quantiplex (Qiagen).

Przeprowadzono analizę regionów HVSI oraz HVSII mitochondrialnego DNA (mtDNA), w zakresie odpowiednio 16024-16365 oraz 73-341 p.z. Użyto primery firmy Applied Biosystems, amplifikację przeprowadzono z zastosowaniem zestawu Qiagen Multiplex PCR Kit, firmy Qiagen. Produkt amplifikacji oczyszczono przy pomocy kolumienek filtracyjnych QIAquick PCR Purification Kit, firmy Qiagen. Sekwencjonowanie prowadzono przy pomocy zestawu BigDye $^{\mathrm{TM}}$ Terminator v 1.1 Cycle Seqvencing Kit (Applied Biosystems). Produkty sekwencjonowania rozdzielano na sekwenatorze genetycznym $A B I$ Prism 310 z użyciem programu Sequencing Analysis 5.2. Otrzymane sekwencje porównano $\mathrm{z}$ sekwencją referencyjną rCRS.

Korzystano z metody Sekwencjonowania Nowej Generacji (NGS), którą przeprowadzono w sekwenatorze MiSeq FGx Forensic Genomic System w oparciu o oprogramowanie ForenSeq Uniwersal Software. System ten umożliwia wykonanie genotypowania przy minimalnej ilości DNA poniżej 1ng.

Haplogrupy ustalono przy pomocy programu dostępnego na stronach www.haplogrep.uibk.ac.at oraz www.empop.online.

\section{WYNIKI}

Szczątki kostne wyeksplorowane z poszczególnych grobów wykazywały różny stan zachowania i stopień degradacji. Najsłabszy stan zachowania wykazywały szczątki wyeksplorowane z grobu nr 13 i 14 (pochówki dziecięce), natomiast najlepszy stan układu kostnego wykazywały szczątki osobnika z grobu nr 15 (osobnik dorosły). W przypadku szkieletów dziecięcych były to liczne drobne fragmenty kości czaszek i fragmenty szkieletów pozaczaszkowych. Kości wykazywały znaczną kruchość, w przypadku kości osobnika z grobu 14 i 16 obserwowano cechy przepalenia.

Stopień degradacji DNA uzyskanego z badanych kości był tak wysoki, że pozytywny wynik uzyskano 
tylko podczas analizy mitochondrialnego DNA grobów 13 i 15.

\section{Grób nr 13}

Szczątki zachowane były fragmentarycznie. Wyróżniono liczne drobne fragmenty czaszki części mózgowej oraz elementy szkieletu pozaczaszkowego - fragmenty kości długich kończyn, kręgów. Wśród szczątków ujawniono zawiązki dwóch zębów - drugiego prawego mlecznego zęba trzonowego żuchwy /85/ i kła szczęki /53/. Ujawnione zawiązki zębów to niecałkowicie zmineralizowane jeszcze korony. Etap rozwoju koron analizowanych zębów mlecznych - górnego kła /53/ i drugiego prawego zęba trzonowego żuchwy /85/ (ryc. 1 A i B) - pozwalają na oszacowanie wieku osobnika w chwili zgonu na około 6-7 miesięcy.

Analiza makroskopowa oraz radiologiczna wyselekcjonowanych fragmentów kostnych szkieletu pozaczaszkowego nie wykazała zmian chorobowych, czy anomalii rozwojowych.

Badania genetyczne szczątków z grobu nr 13 ze względu na degradację DNA nie dostarczyły jednoznacznych wyników dotyczących płci badanego osobnika. Wstępne badania szczątków z grobu 13 w zakresie markera amelogeniny, który dostarcza informacji na temat płci genetycznej, wskazują na płeć żeńską. Uzyskane haplotypy mitochondrialnego DNA (mtDNA) pozwoliły na oszacowanie przynależności osobnika do haplogrupy JT.

Profil osobnika z grobu nr 13:

płeć: wstępne wyniki badań genetycznych wskazują na płeć żeńską

wiek: dziecko infans I (około 6-7 miesięcy)

wysokość ciala: -

masa ciała: -

haplogrupa: JT

\section{Grób nr 14}

Szczątki zachowane były fragmentarycznie i wykazywały cechy przepalenia. Wyróżniono 679 drobnych fragmentów czaszki (części mózgowej i części twarzowej) oraz wiele elementów szkieletu pozaczaszkowego - m.in. fragmenty kości długich kończyn, fragmenty kręgów, których cechy morfologiczne wskazują na cechy szkieletu dziecięcego. Wśród szczątków stwierdzono występowanie izolowanych

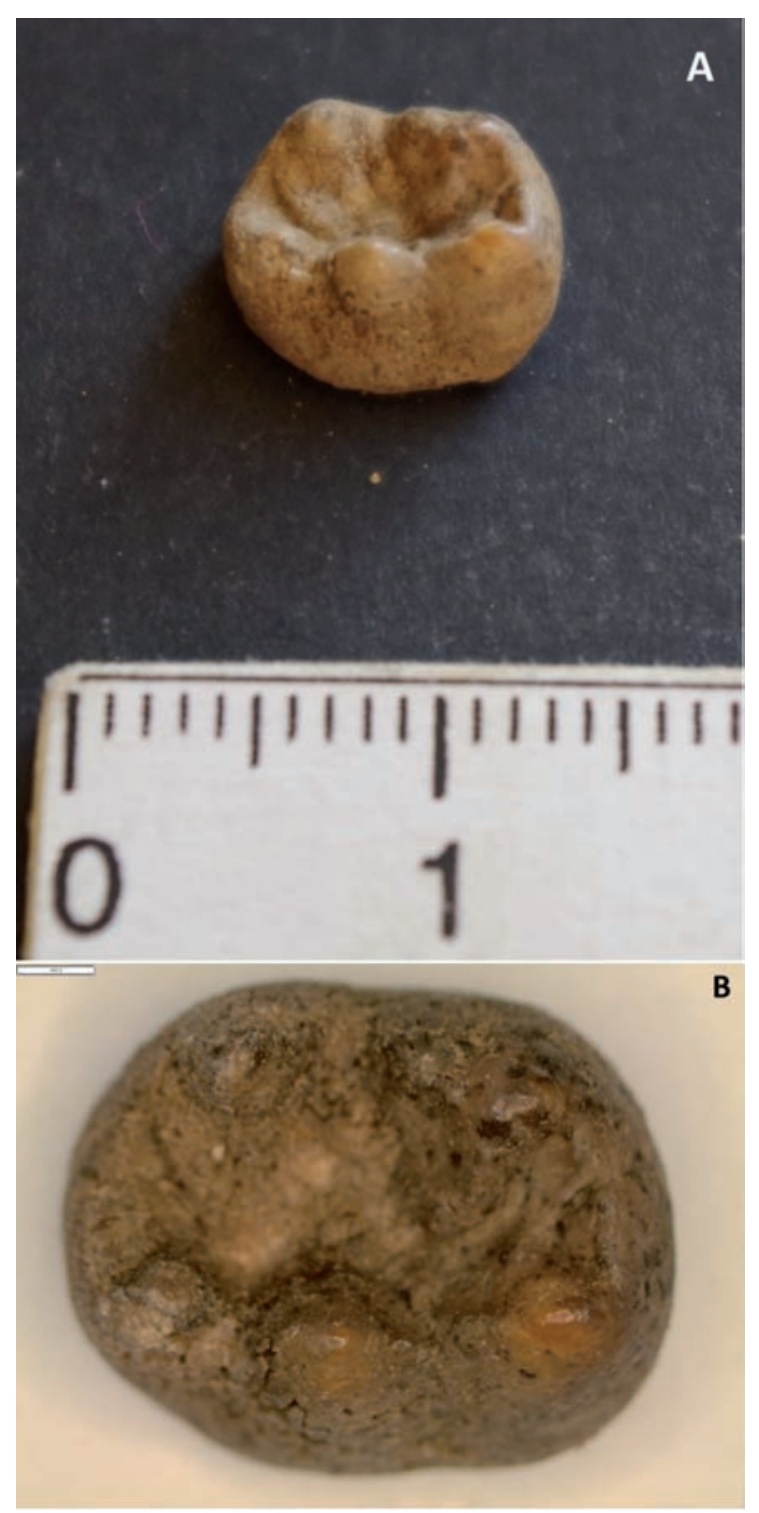

Ryc. 1. Grób nr 13. Zdjęcia mlecznego drugiego prawego zęba trzonowego żuchwy /85/ - zdjęcie fotograficzne (A), zdjęcie spod mikroskopu stereoskopowego (B). Fot. D. Lorkiewicz-Muszyńska

Fig. 1. Grave No. 13. Images of the developing (crown stage) right second lower primary molar /85/ - photo (A), stereomicroscopic image (B). Photo by D. Lorkiewicz-Muszyńska

korzeni zębów w fazie zakończonego rozwoju, jeden kieł mleczny (zakończona mineralizacja). W zachowanym fragmencie żuchwy (część prawa trzonu żuchwy) stwierdzono brak pierwszego stałego zęba trzonowego /46/ (otwarty i głęboki zębodół), wolny zębodół dla zawiązka drugiego stałego zęba trzonowego /47/, oraz widoczna jest w zębodole korona drugiego stałego zęba przedtrzonowego /45/ w fazie rozwoju. Wśród materiałów kostnych znaleziono luźne dwa zawiązki bocznych stałych siekaczy szczęki 


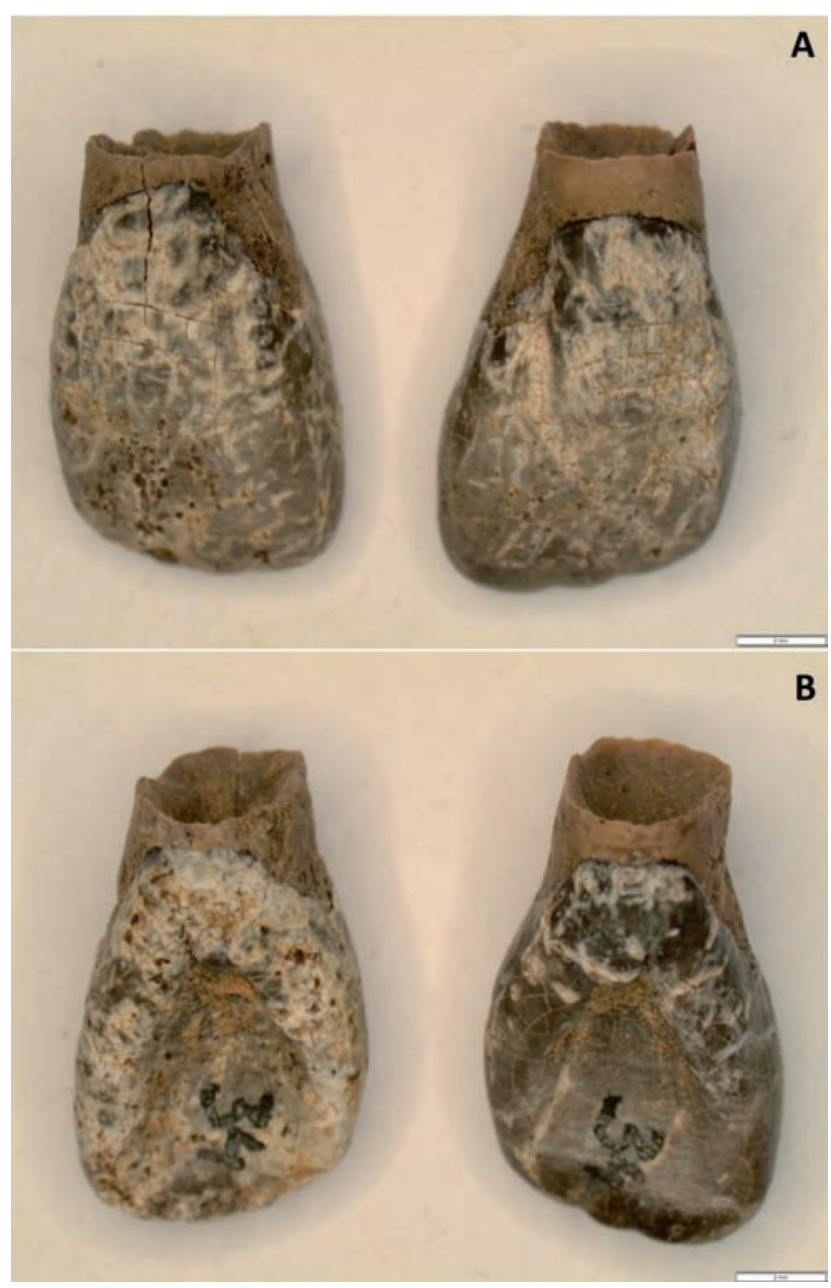

Ryc. 2. Grób nr 14. Zdjęcia obu bocznych siekaczy szczęki /21 i 22/ osobnika z grobu nr 14 spod mikroskopu stereoskopowego (A - powierzchnia wargowa, B - powierzchnia językowa).

Fot. D. Lorkiewicz-Muszyńska

Fig. 2. Grave No. 14. Stereomicroscopic images of developing both lateral incisors (A - labial surface, B - lingual surface). Photo by D. Lorkiewicz-Muszyńska

/11, 21/, zawiązek stałego pierwszego prawego zęba przedtrzonowego szczęki /14/ oraz zawiązek stałego drugiego zęba trzonowego szczęki /17/. Korony zębów wykazują spękania szkliwa (ryc. 2 A, B; 3). W przypadku obu bocznych siekaczy szczęki obserwuje się obecne mamelony (ryc. 2 A, B), w postaci trzech guzków występujących na brzegach siecznych. Mamelony to pofałdowanie brzegu siecznego charakterystyczne dla świeżo wyrzniętych siekaczy, które szybko ulegają starciu podczas użytkowania zębów. Wśród szczątków znaleziono także fragmenty innych zębów, lecz z uwagi na ich fragmentaryczność bliższa analiza nie była możliwa.

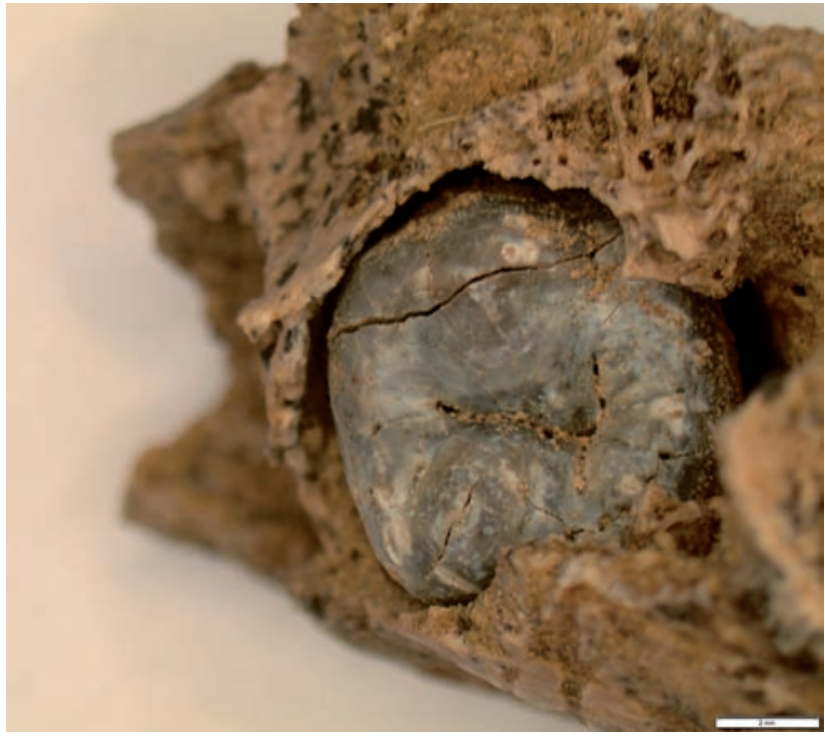

Ryc. 3. Grób nr 14. Zdjęcie zawiązka (etap korony) stałego drugiego prawego zęba przedtrzonowego żuchwy /45/ spod mikroskopu stereoskopowego.

Fot. D. Lorkiewicz-Muszyńska

Fig. 3. Grave No. 14. Stereomicroscopic image of developing (crown stage) of the right second lower permanent premolar $/ 45 /$. Photo by D. Lorkiewicz-Muszyńska

Wiek zębowy określono wg stadiów rozwoju zębów wg Haavikko (1970) na podstawie rozwoju dwóch bocznych siekaczy szczęki 12 i 22 (R1/4); zęba trzonowego 17 (Crc), zęba 17 (stadium Crc), zęba 45 (stadium nieco ponad $\mathrm{Crc}$ ), na około 7 lat.

Poza jamą grobową zaobserwowano dwa fragmenty kości czaszki (części mózgowej) oraz paliczek dalszy należące do innego osobnika.

\section{Profil osobnika z grobu nr 14:}

płeć: - (degradacja DNA, badania genetyczne są kontynuowane)

wiek: dziecko infans I/infans II (około 7 lat)

wysokość ciala: -

masa ciała: -

haplogrupa: -

Kości zwierzęce: obecne fragmenty kości zwierzęcych.

\section{Grób nr 15}

Czaszka zachowana wraz z żuchwą. W części mózgowej stwierdza się ubytki w okolicy podstawy czaszki, w części twarzowej ubytki występują w zakresie kości szczękowej i kości nosowej po stronie prawej. Kości czaszki są masywne, wykazują bardzo 
dobrze ukształtowaną rzeźbę przyczepów mięśniowych. Podstawowe szwy czaszkowe: szew wieńcowy (s. coronalis): w odcinku C1 wykazuje początkowe zarastanie, odcinek C2 otwarty, w odcinku C3 szew zarośnięty; szew strzałkowy (s. sagittalis) - w odcinku S1 stwierdza się początkową obliterację, w S2 szew wykazuje niemal pełną obliterację, w odcinku S3 szew zarośnięty, w S4 szew niemal zarośnięty; szew węgłowy (s. lambdoidea) - w odcinku L1 wykazuje początkowe zarastanie, w odcinkach L2 i L3 szew otwarty.

Cechy kranioskopijne: silne pochylenie łuski kości czołowej, wyraźnie ukształtowane łuki nadbrwiowe, nie zaobserwowano guzów czołowych, oczodoły kształtu prostokątnego; szerokie zaokrąglone brzegi nadoczodołowe, wyraźnie ukształtowana guzowatość bródkowa, duże i masywne wyrostki sutkowate z silnie ukształtowaną rzeźbą przyczepów mięśniowych (zdjęcia czaszki: ryc. 4: A-C).

Stwierdzono także występowanie cech niemetrycznych, takich jak: wcięcie nadoczodołowe (brzeg nadoczodołowy prawy), dwa otwory nadoczodołowe (brzeg nadoczodołowy lewy), os asterion.

Na czaszce wykonano standardowe pomiary wg metodyki R. Martina (Martin, Saller 1957) (tab. 1). Wyniki pomiarów wykorzystano do obliczenia wskaźników opisujących proporcje budowy czaszki (tab. 2). Wskaźniki charakteryzują czaszkę jako bardzo długą (hyperdolichocranius), wysoką (akrocranius), o czole szerokim (eurymetopus), twarzy wąskiej (lepto- prosopus), nosie wąskim (leptorrhinus), oczodołach niskich (chamaekonch).

\section{Stan zachowania uzębienia:}

\section{Szczęka:}

Strona prawa - wyrostek zębodołowy wykazuje uszkodzenia, obserwuje się zaawansowane zmiany erozyjne, brakuje części dystalnej wyrostka zębodolowego;

Strona lewa - w szczęce zachowany pierwszy ząb przedtrzonowy /24/, puste i głębokie zębodoły w miejscu brakujących zębów 22, 23, 25, 27. Zarośnięty zębodół w miejscu brakującego zęba 28 . W okolicy zębodołu dla zęba 21 (centralny siekacz) wyrostek zębodołowy uszkodzony w wyniku naturalnych zmian erozyjnych.

Widoczny okrągły ubytek kości dna zatoki szczękowej lewej o średnicy $6 \mathrm{~mm}$, w miejscu korzenia podniebiennego zęba 26 . Widoczny lejkowaty kształt ubytku kostnego związany z toczącym się za życia, przez dhugi okres, procesem zapalnym.

\section{Żuchwa:}

Strona prawa - obserwuje się puste i głębokie zębodoły w miejscu brakujących zębów 41, 42, 45, 46, 47, 47. Brakuje także zębów 43 i 44, a zębodoły są zarośnięte. Kość części zębodołowej w okolicy 43-44 wykazuje cechy toczącego się za życia stanu zapalnego przyzębia związanego z zębami 43 i 44 . Zęby mogły być obecne w jamie ustnej bądź też mogły zostać utracone w przedziale kilku miesięcy przed śmiercią i stąd brak całkowitego wygojenia kości.

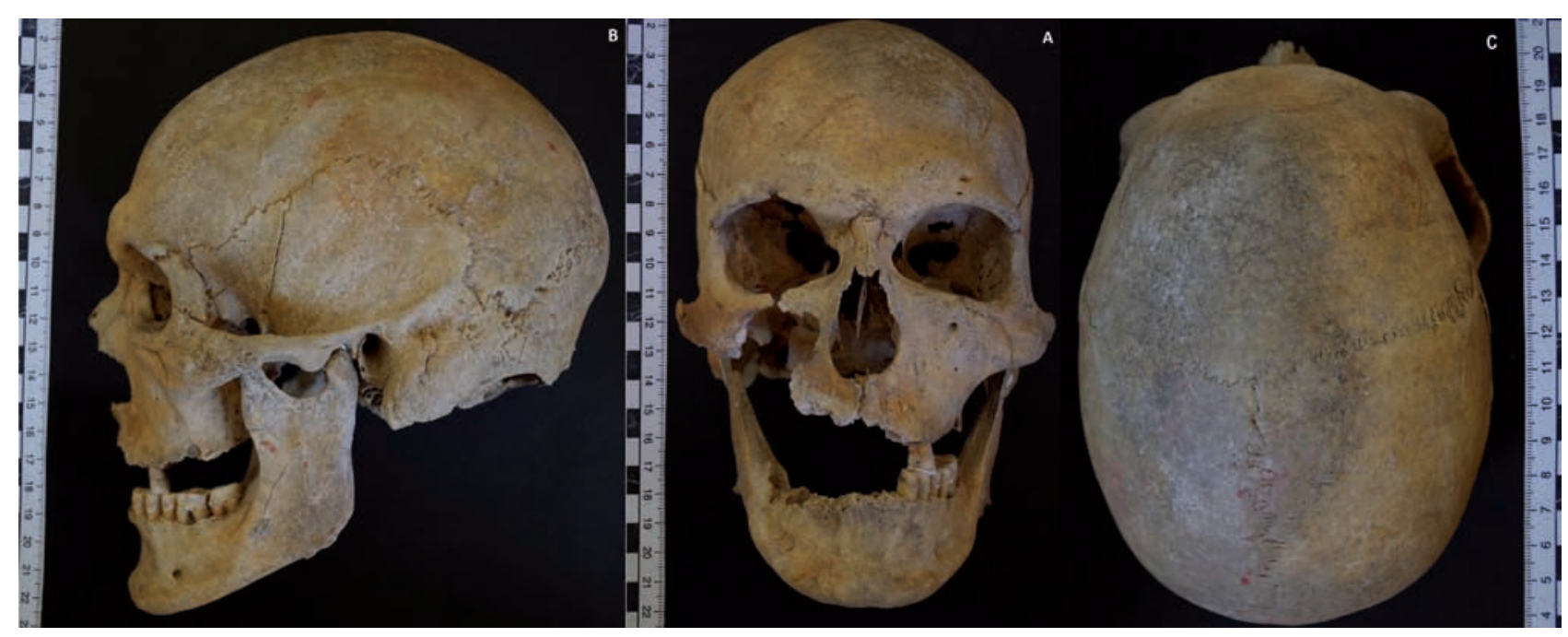

Ryc. 4. Grób nr 15. Zdjęcia czaszki w norma frontalis (A), norma lateralis (B) i norma verticalis (C). Fot. D. Lorkiewicz-Muszyńska

Fig. 4. Grave No. 15. Images of the skull in norma frontalis (A), norma lateralis (B) and norma verticalis (C).

Photo by D. Lorkiewicz-Muszyńska 
Tabela 1. Grób nr 15. Pomiary czaszki

Table 1. Grave No 15. Skull measurements

\begin{tabular}{|c|c|c|c|}
\hline Pomiar & Wartość & Pomiar & Wartość \\
\hline eu-eu & 126 & $n-b$ & 116 \\
\hline$b a-b$ & 141 & co-co & 121 \\
\hline$g-o p$ & 188 & $a s t-a s t$ & 112 \\
\hline$f t-f t$ & 93 & $a u-a u$ & 127 \\
\hline zy-zy & 142 & mf-ek & 43 \\
\hline$m s-m s$ & 111 & wys. oczodotu & 30 \\
\hline $\mathrm{n}-\mathrm{ba}$ & 103 & $e k-e k$ & 101 \\
\hline $\mathrm{n}-\mathrm{gn}$ & 132 & go-go & 99 \\
\hline$n-n s$ & 56 & id-gn & 38 \\
\hline$a p t-a p t$ & 24 & $n-p r$ & - \\
\hline
\end{tabular}

Tabela 2. Grób nr 15. Wskaźniki czaszkowe

Table 2. Grave No. 15. Cranial index

\begin{tabular}{|l|c|c|}
\hline \multicolumn{1}{|c|}{ wskaźnik } & wartość & klasyfikacja wskaźnika \\
\hline wskaźnik szerokościowo-długościowy & 68,6 & hyperdolichocranius (bardzo długa) \\
\hline wskaźnik wysokościowo-dtugościowy & 75 & hipsikranius (długoczaszkowy) \\
\hline wskaźnik wysokościowo-szerokościowy & 111.9 & akrocranius (wysokoczaszkowy) \\
\hline wskaźnik czołowo-szerokościowy & 73,8 & eurymetopus (szerokoczołowy) \\
\hline wskaźnik twarzy & 92,9 & leptoprosopus (wąskotwarzowy) \\
\hline wskaźnik twarzy górnej & - & \\
\hline wskaźnik nosa & 42,8 & leptorrhinus (wąsonosowy) \\
\hline wskaźnik oczodołów & 69,7 & chamaekonch (niskooczodołowy) \\
\hline
\end{tabular}

Strona lewa - puste i głębokie zębodoły w miejscu brakujących zębów 31, 32. Zachowane zęby 33, 34, 35, 36, 37. Brak zęba 38 .

Wśród szczątków wyróżnia się luźne zęby - lewy drugi ząb trzonowy szczęki /17/ - bez zmian chorobowych; prawy kieł szczęki /13/; centralny siekacz lewy szczęki /21/; boczny siekacz lewy szczęki /22/ oraz pierwszy lewy ząb trzonowy szczęki /26/. W zębie 26 obserwuje się rozległy ubytek próchnicowy (pulpa aperta, współcześnie klasyfikowana jako próchnica głęboka z obnażeniem miazgi), jako powikłania stanu zapalnego miazgi (ryc. 5 B). W następstwie przewlekłego procesu zapalnego w miejscu dla korzenia bliższego widoczne jest ognisko osteolizy sugerujące obecność przewlekłego zapalenia tkanek (ryc. $5 \mathrm{~A}$ ).

Zachowane w łukach zęby, jak również zęby luźne, wykazują zaawansowany stopień starcia koron, przeważnie z odsłonięciem zębiny (ryc. $6 \mathrm{~A} \mathrm{i} \mathrm{C).}$ 


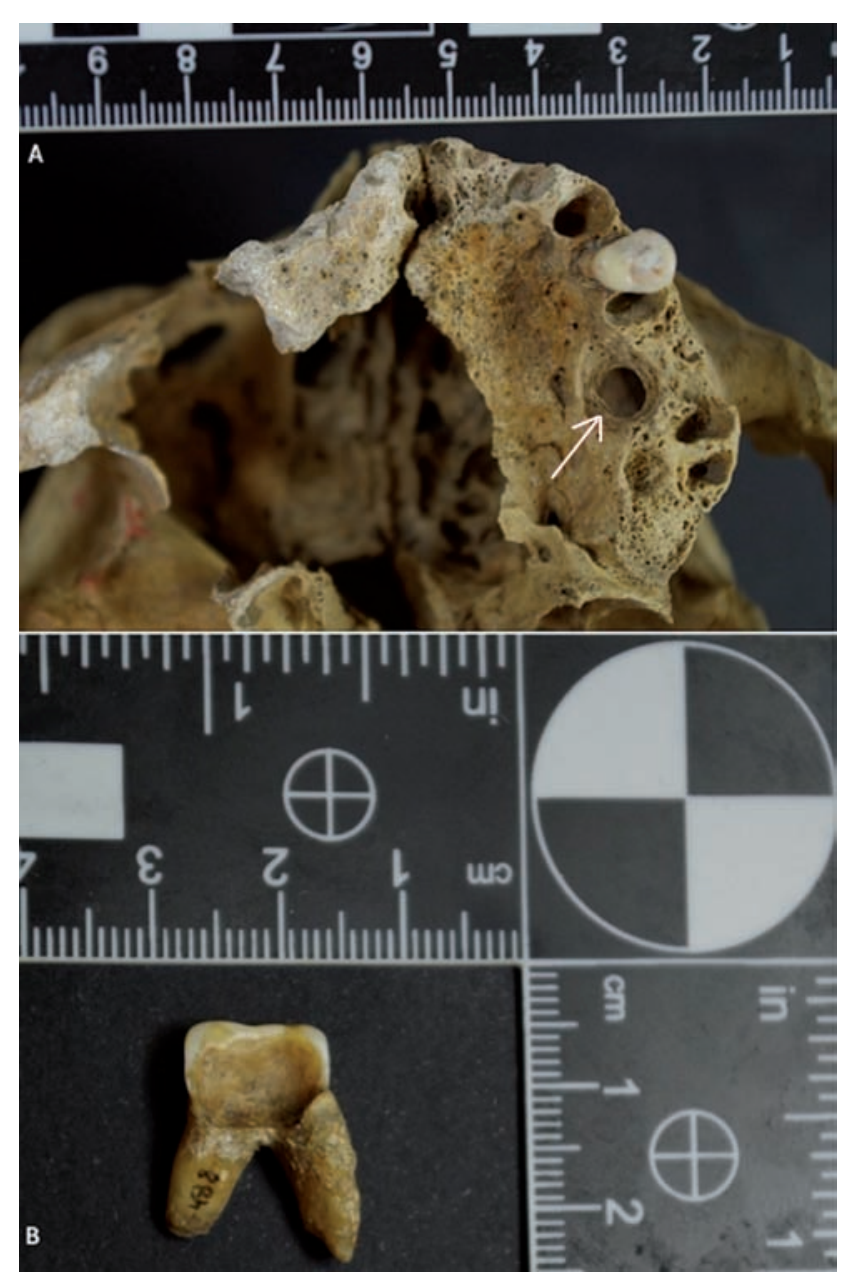

Ryc. 5. Grób nr 15. Zdjęcie przedstawiające stan zachowania uzębienia szczęki - strzałką oznaczono zmiany kostne związane z toczącym się przez długi okres procesem zapalnym w zęba (A). Ząb 26 z dużym ubytkiem o charakterze próchnicowym (B). Fot. D. Lorkiewicz-Muszyńska

Fig. 5. Grave No. 15. Maxilla with one tooth within alveolar socket (A). Features of antemortem periapical inflammation and healing alveolar socket, in place of missing tooth 26 were observed indicated by the arrow. Periapical pathology in 26 (B).

Photo by D. Lorkiewicz-Muszyńska

Wykonano zdjęcia rentgenowskie czaszki, AP i boczne (ryc. 7 A i B) oraz badanie tomografii komputerowej żuchwy (ryc. 8 A i B). Zatoka czołowa na obrazach rtg dobrze widoczna, ukształtowana obustronne, wielokomorowa. Największy wymiar poprzeczny zatoki wynosi 79,8 mm (ryc. 7).

Stan zachowania i budowa kości szkieletu pozaczaszkowego jest $\mathrm{w}$ dobrym stanie. W kręgosłupie zaobserwowano braki oraz uszkodzenia pośmiertne zachowanych kręgów. Odnotowano pięć kręgów szyjnych $\mathrm{w}$ różnym stanie zachowania, $\mathrm{w}$ tym kręgi

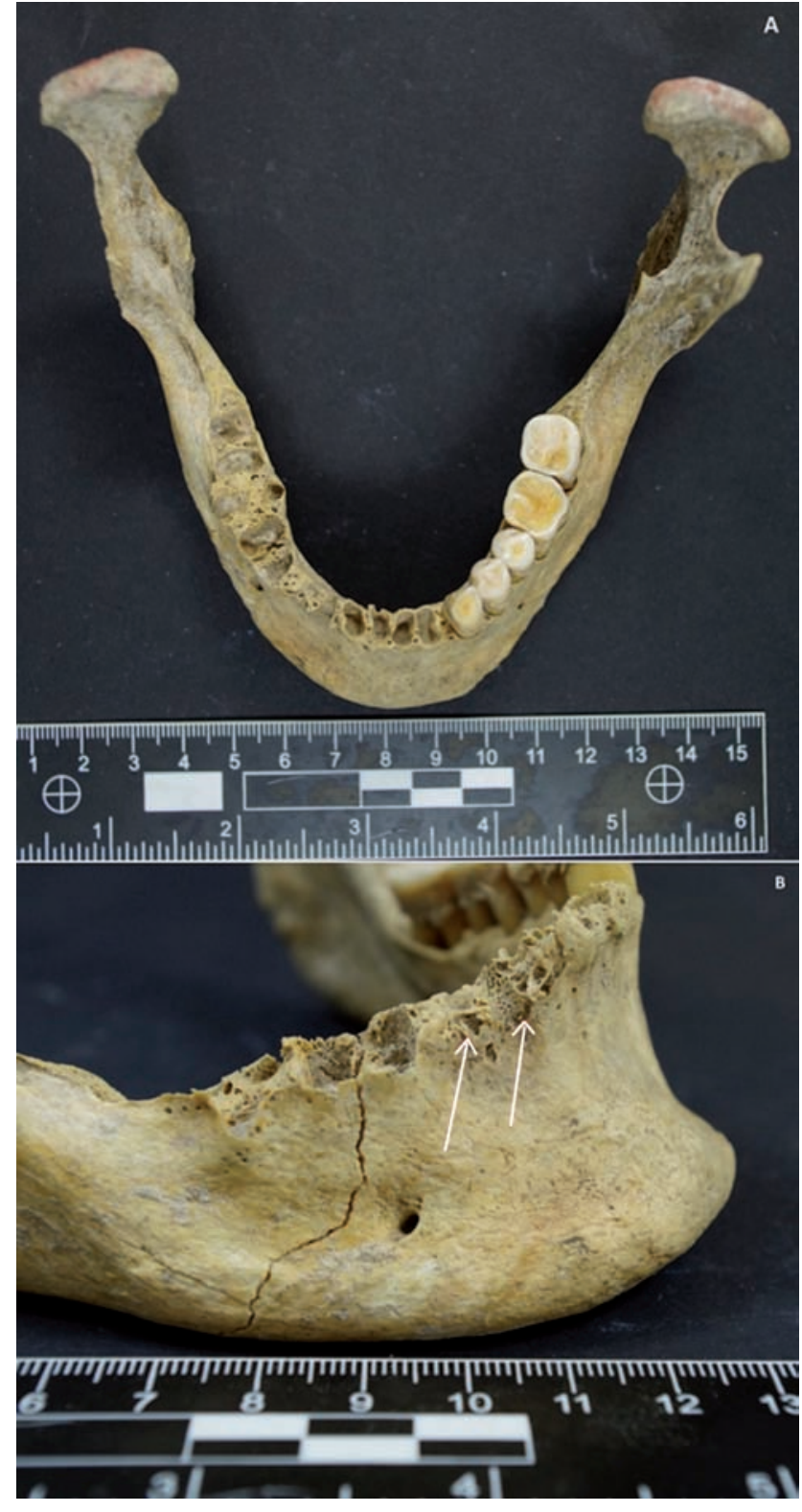

Ryc. 6. Grób nr 15. Zdjęcia żuchwy z zębami w zębodołach (A, B). Kość części zębodołowej w okolicy 43-44 wykazuje cechy toczącego się za życia stanu zapalnego przyzębia - oznaczono strzałkami (B). Fot. D. Lorkiewicz-Muszyńska

Fig. 6. Grave No. 15. Mandible with teeth within alveolar sockets (A, B). Alveolar bone around 43-44 show the features of antemortem periodontal inflammation - indicated by the arrow.

Photo by D. Lorkiewicz-Muszyńska

C1 (atlas) i C2 (axix) zachowane kompletnie. W przypadku kręgu $\mathrm{C} 1$ obserwuje się mostek kostny tylny po stronie lewej (ryc. 9). Po stronie prawej obserwowany jest mostek częściowy lub też pierwotnie mógł występować mostek pełny, który mógł ulec uszkodzeniu pośmiertnie, o czym świadczy stan kości. Kręgi piersiowe w liczbie 7 zachowały się częściowo, w tym 


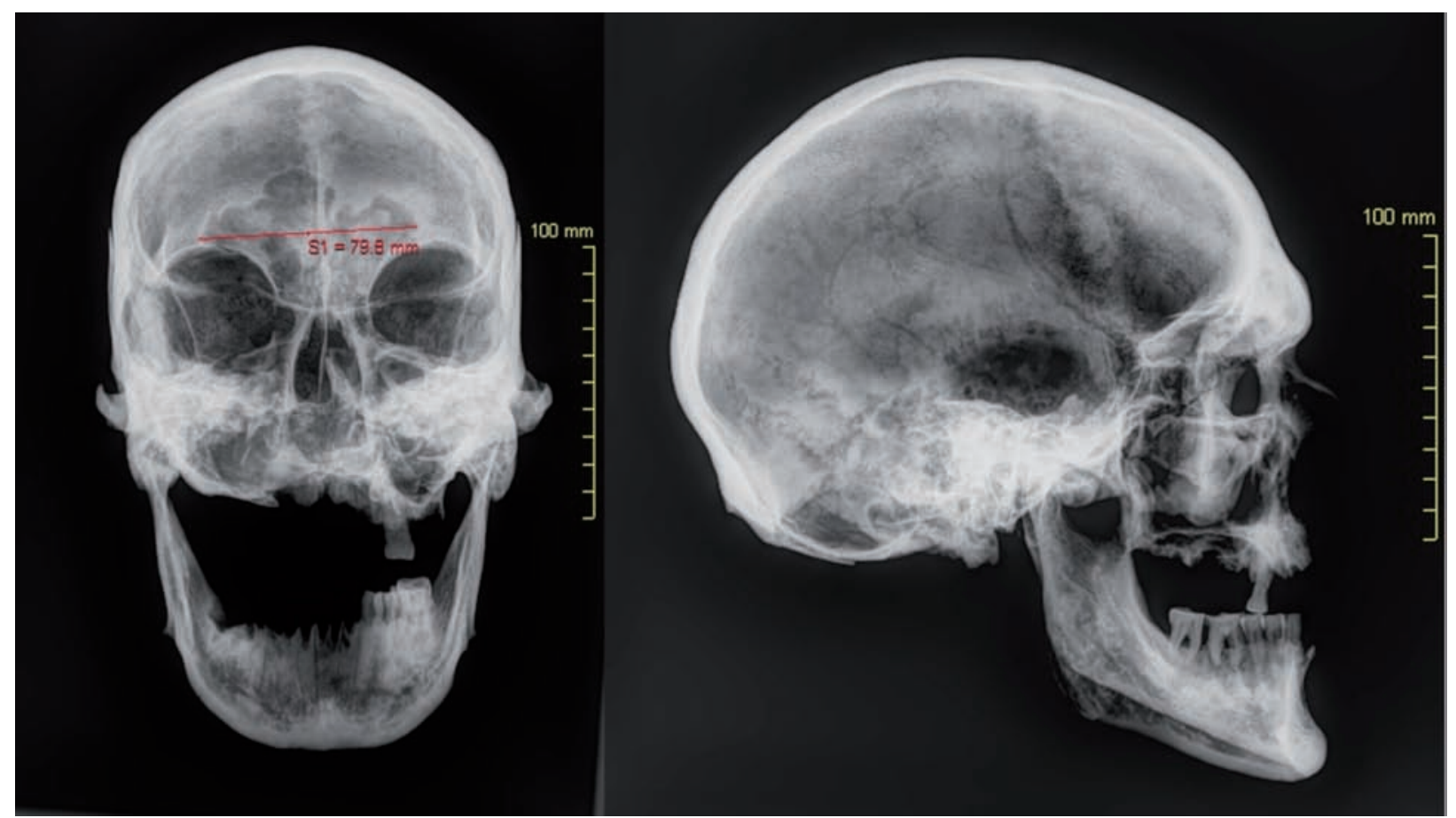

Ryc. 7. Grób nr 15. Zdjęcie rentgenowskie AP (A) i boczne (B) czaszki. Wykonano pomiar poprzeczny największej szerokości zatoki czołowej. Fot. D. Lorkiewicz-Muszyńska

Fig. 7. Grave No. 15. AP and lateral X-ray of the skull. Measured parameters of the frontal sinus, maximum total width. Photo by D. Lorkiewicz-Muszyńska

w odcinku piersiowym wyróżnia się dwa bloki kostne (ryc. 10 A-C). Każdy blok kostny powstał ze zrośnięcia dwóch sąsiadujących kręgów. Pełne bloki kostne o charakterze wrodzonym i prawie całkowitym zatarciu przestrzeni międzykostnej obejmują trzony, nasady łuków, stawy międzykręgowe i wyrostki z zachowaniem drożności kanału kręgowego i otworów międzykręgowych. Zachowane są częściowo wszystkie kręgi lędźwiowe, które wykazują na obrzeżach trzonów drobne zmiany o charakterze przeciążeniowym. Częściowo zachowana jest kość krzyżowa (uszkodzona i w kilku fragmentach).

W zakresie zachowanych kręgów obserwuje się zmiany o charakterze przeciążeniowym $\mathrm{w}$ postaci osteofitów na obwodach trzonów, a na górnych i dolnych powierzchniach trzonów ślady guzków Schmorla.

Spośród kości klatki piersiowej wyróżniono wiele różnej wielkości ułamków żeber, które cechują się dużymi rozmiarami i znaczną masywnością. W przypadku zachowanych części obejmujących guzki żeber zaobserwowano zmiany degeneracyjne powierzchni stawowych guzków żeber.

Z kości obręczy barkowej zachowane są oba obojczyki, lewy złamany post mortem w części środkowej trzonu. Na obojczykach obserwuje się zazna- czone wyznaczniki stresu mięśniowo-szkieletowego (MSM). Szczególnie wyraźnie ukształtowane zmiany obserwuje się na końcach barkowych, które są szerokie, silnie spłaszczone od góry do dołu, „łopatowatego" kształtu, z silnie zaznaczonymi i uwydatnionymi miejscami przyczepów mięśni i więzadeł. Wyraźnie ukształtowany jest guzek stożkowaty na obu kościach. Obserwuje się wyraźnie zaznaczoną rzeźbę powierzchni przyczepów części obojczykowej mięśnia naramiennego ( $m$. deltoideus) wyrażoną obecnością chropowatych wyniosłości i grzbietów oraz drobnych wyrośli kostnych. Wyznaczniki stresu mięśniowo-szkieletowego są nieco silniej zaznaczone na obojczyku lewym. Częściowo zachowane obie łopatki o dużych, masywnych wyrostkach barkowych i kruczych. W przypadku wyrostków barkowych obserwuje się wyraźnie zaznaczone zmiany powierzchni przyczepów części barkowej (w postaci dołków) i części grzebieniowej (w postaci grzbietów) mięśnia naramiennego ( $m$. deltoideus). Zmiany nieco silniej wyrażone są na kości prawej na powierzchni przyczepów części barkowej, a na kości lewej przyczepów części grzebieniowej mięśnia naramiennego. Obserwuje się silnie wyrażone zmiany powierzchni guzka podpanewkowego łopatki prawej - miejsca przyczepu głowy długiej mięśnia trójgłowego ramienia 


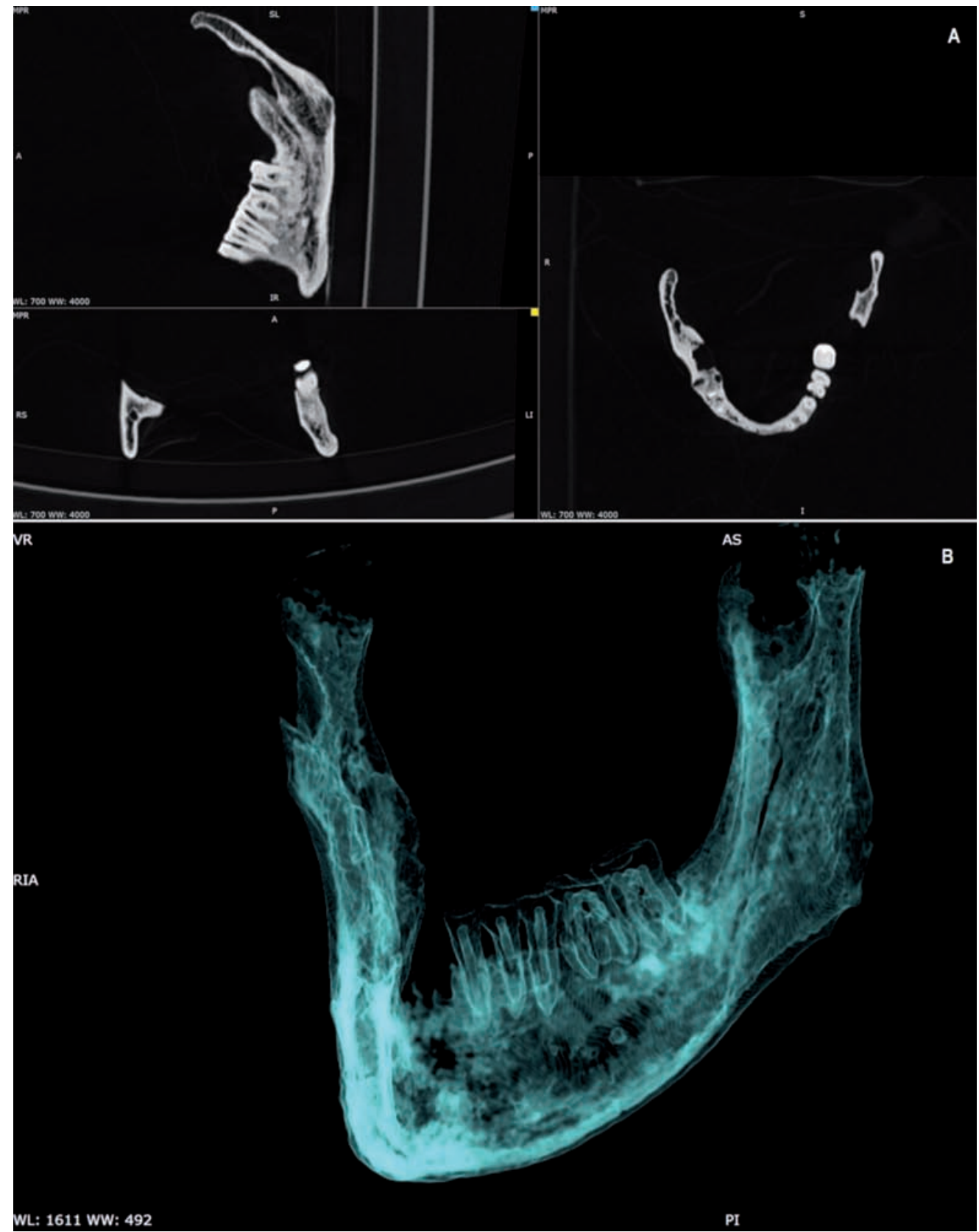

Ryc. 8. Grób nr 15. Rekonstrukcje tomograficzne żuchwy -2D (A) i 3D air (B). Fot. D. Lorkiewicz-Muszyńska Fig. 8. Grave No. 15. Tomographic reconstructions of the mandible - 2D (A) and 3D air (B). Photo by D. Lorkiewicz-Muszyńska

(m. triceps brachii, caput longum). Zmiany wyrażone są w postaci rowków i chropowatych wyniosłości. Powierzchnia grzbietowa brzegu bocznego łopatki prawej, w miejscach przyczepów mięśnia obłego mniejszego (m. teres minor) wykazuje linijne chropowate wyniosłości. Analogiczne okolice łopatki lewej nie są możliwe do oceny z uwagi na jej częściowy stan zachowania. Na uwagę zasługuje także zaznaczenie zmian górnych powierzchni wyrostków kruczych obu łopatek w miejscach przyczepów mięśnia piersiowego mniejszego ( $m$. pectoralis minor).
Kości kończyn górnych są niekompletnie zachowane. Zachowane są kości ramienne, bez uszkodzeń. Kości ramienne są dużych rozmiarów, masywne, cechują się trzonem S-owatego kształtu i silnie ukształtowanymi wyniosłościami, guzowatościami, chropowatymi grzbietami i dołków i rowków w miejscach przyczepów mięśni i więzadeł w wyniku oddziaływania na nie znacznych sił podczas pracy tkanek mięśni (ryc. 11, 12). W przypadku obu kości obserwuje się silnie ukształtowaną guzowatość naramienną (tuberositas deltoidea), do której powierzchni przyczepia 


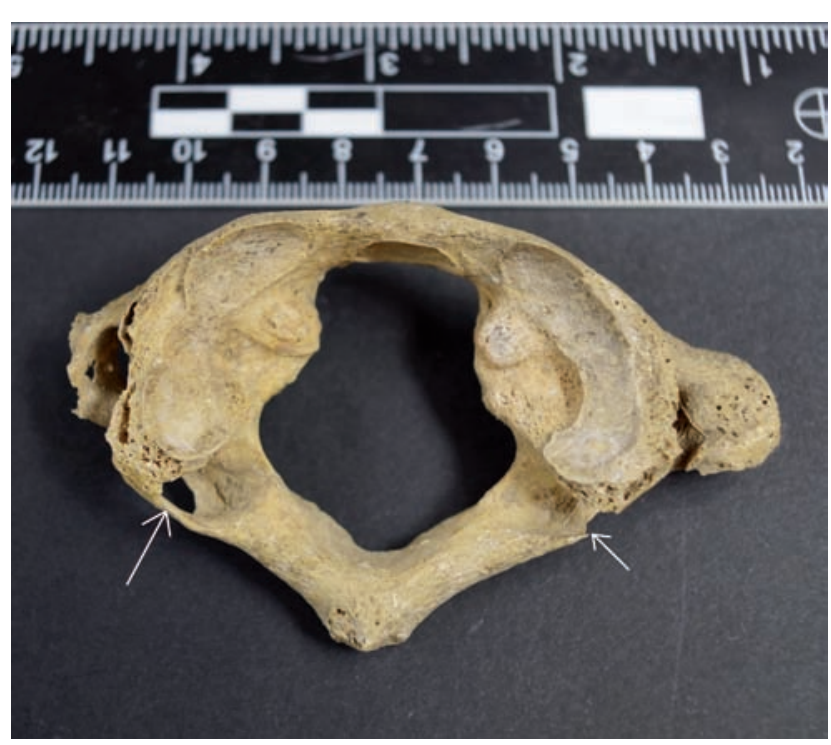

Ryc. 9. Pierwszy kręg szyjny S1 (atlas) z szkieletu z grobu nr 15. Strzałką oznaczono mostek kostny.

Fot. D. Lorkiewicz-Muszyńska

Fig. 9. Image of the atlas vertebra (C1) from a skeleton from grave No. 15 showing a unilateral complete osseous bridge (indicated by the arrow).

Photo by D. Lorkiewicz-Muszyńska

się mięsień naramienny ( $m$. deltoideus). Wyróżnia się także silnie ukształtowane listewki kostne, szczególnie listewkę boczną (grzebień guzka większego), który jest miejscem przyczepu mięśnia piersiowego większego (m. pectoralis major). Mniej wyraźnie jest zaznaczona listewka przyśrodkowa (grzebień guzka mniejszego).

Zachowane są kości promieniowe i łokciowe, duże i masywne. W przypadku kości promieniowych uwagę zwracają silnie zaznaczone chropowate zmiany powierzchni i zaznaczenie brzegów: guzowatość kości promieniowej (tuberositas radii) będąca miejscem przyczepu mięśnia dwugłowego ramienia ( $m$. biceps brachii), grzebień międzykostny (crista interossea) będący miejscem przyczepu błony międzykostnej (interosseus membrane), powierzchnia boczna części środkowej trzonu będąca miejscem przyczepu mięśnia nawrotnego obłego ( $m$. pronator teres) oraz miejsca przyczepów mięśni w zakresie końca dalszego kości łokciowej, jak mięsień ramienno-promieniowy (m. brachioradlialis) czy mięsień nawrotny czworoboczny ( $m$. pronator quadratus). Kości łokciowe w zakresie końca bliższego wykazują wyraźnie ukształtowane listewki kostne na obwodzie powierzchni stawowych wyrostka łokciowego i wyrostka dziobiastego. W swej znacznej masywności i silnym stopniu ukształtowania rzeźby kości łokcio-
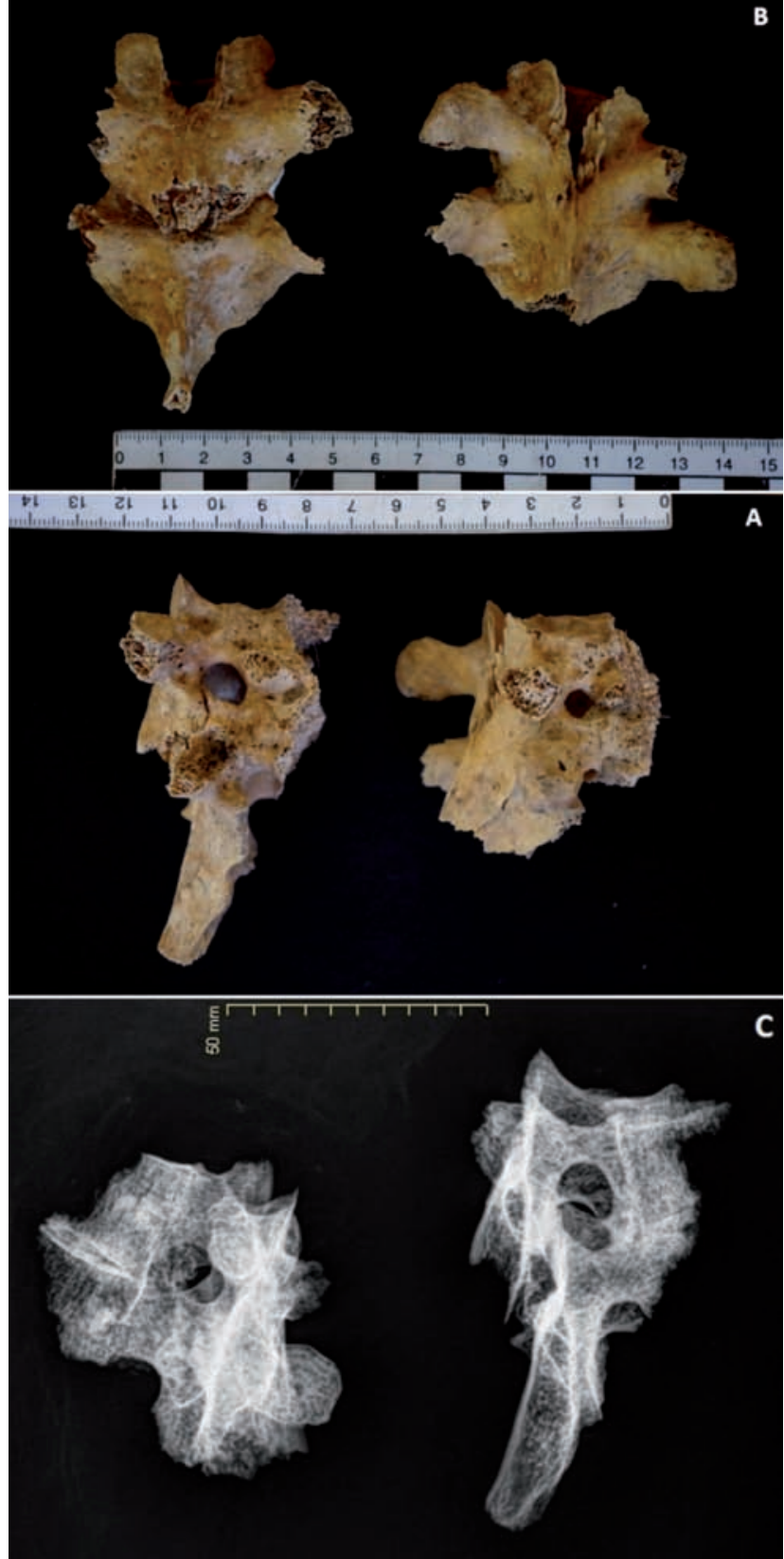

Ryc. 10. Grób nr 15. Zdjęcia fotograficzne (A, B) oraz rentgenowskie (C) kręgów odcinka piersiowego. Wrodzone anomalie - całkowite kostne bloki kręgów obejmujące przednie tylne oraz boczne elementy.

Fot. D. Lorkiewicz-Muszyńska, W. Kociemba Fig. 10. Grave No. 15. Images and X-ray of thoracic vertabrae of individual. Congenital vertebral anomaly

- the complete block vertebra involving anterior, posterior and laterals elements. Photo by W. Kociemba, D. Lorkiewicz-Muszyńska

wych na szczególną uwagę zwracają: grzebień międzykostny (crista interossea) będący miejscem przyczepu błony międzykostnej (interosseus membrane), guzowatość kości łokciowej (tuberositas ulnae) dla przyczepu mięśnia ramiennego ( $m$. brachialis) 


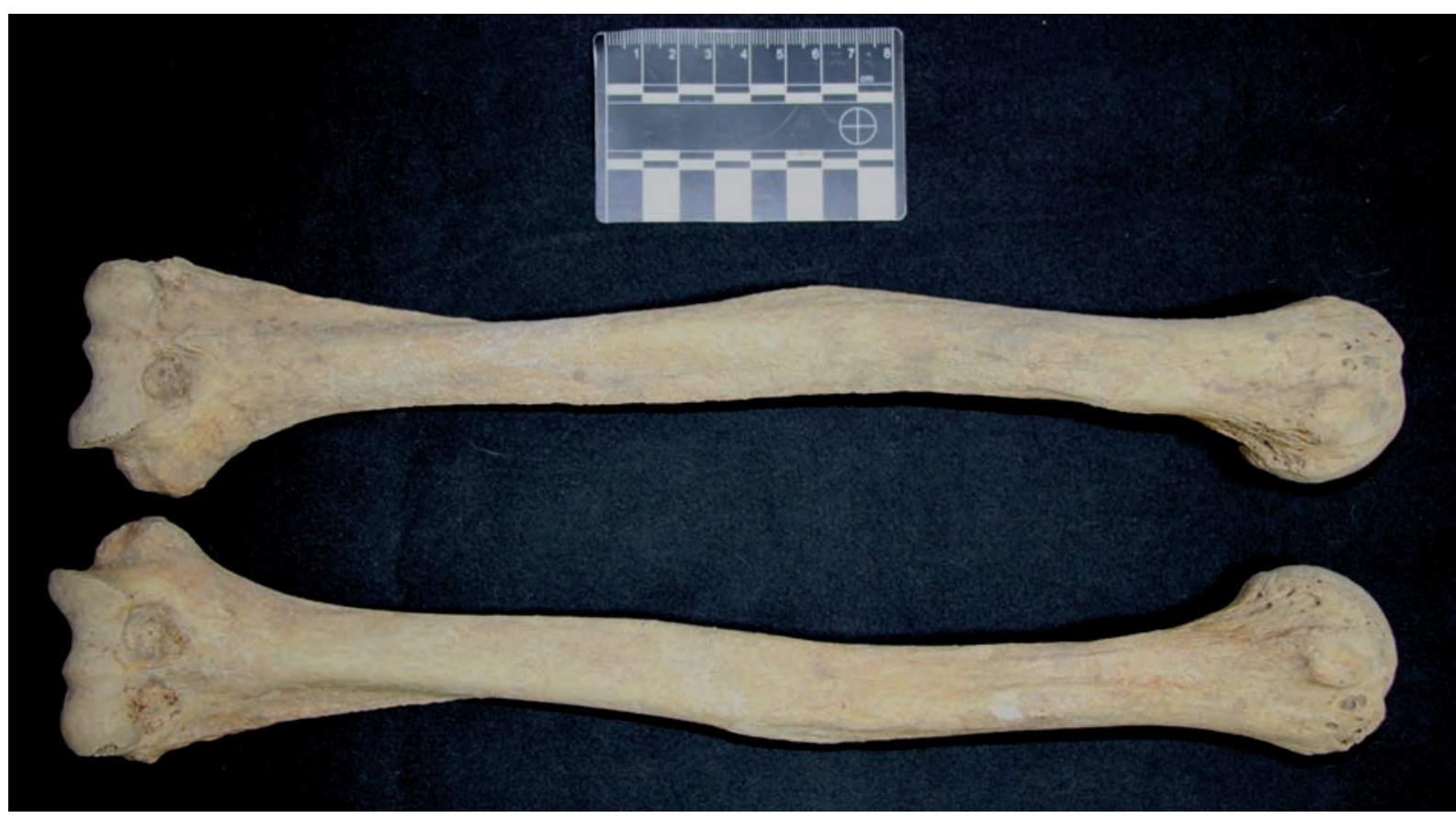

Ryc. 11. Wyznaczniki stresu mięśniowo-szkieletowego (MSM) na kościach ramiennych. Fot. D. Lorkiewicz-Muszyńska Fig. 11. Musculoskeletal Stress Markers (MSMs) expression on the humerus bones. Photo by D. Lorkiewicz-Muszyńska

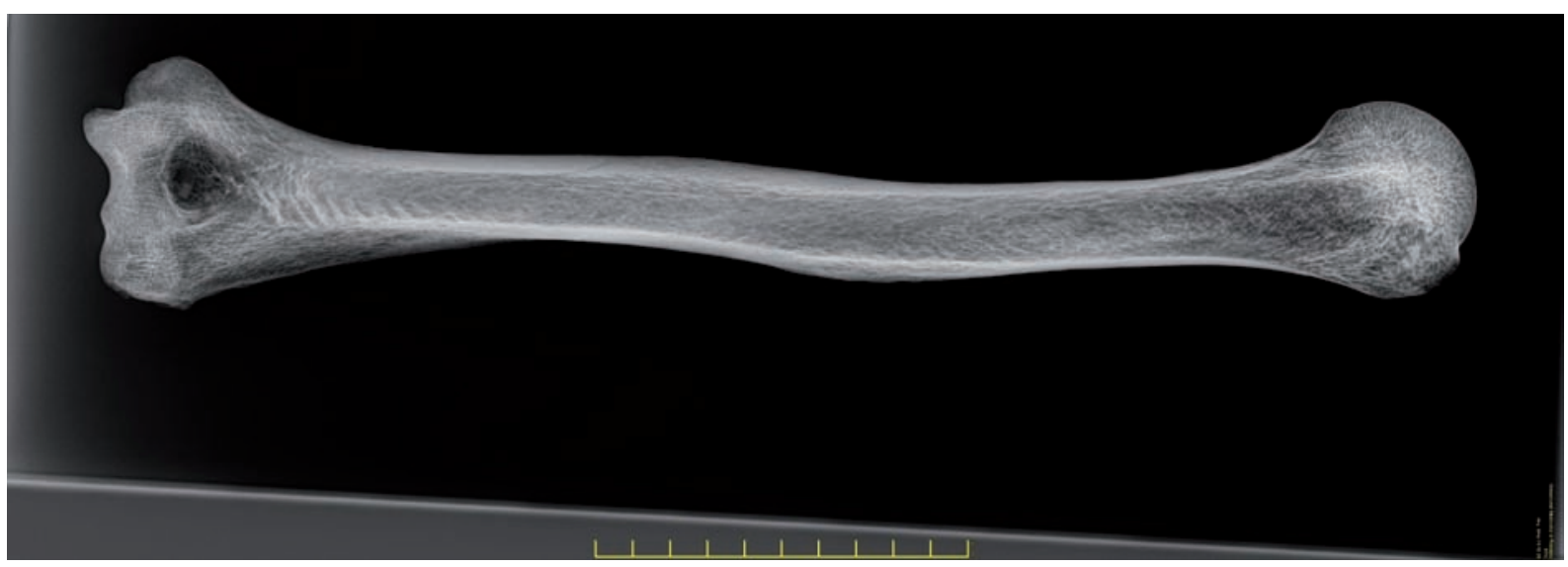

Ryc. 12. Zdjęcie rentgenowskie kości ramiennej lewej osobnika z grobu nr 15. Fot. W. Kociemba, D. Lorkiewicz-Muszyńska

Fig. 12. X-ray of the left humerus of the individual from the grave No. 15. Photo by W. Kociemba, D. Lorkiewicz-Muszyńska

oraz powierzchnie przyczepów mięśnia odwracacza (m. supinator), mięśnia zginacza głębokiego palców (m. flexor digitorum profundus), miejsce przyczepu głowy łokciowej mięśnia nawrotnego obłego (m. pronator teres) na wyrostku dziobiastym, czy powierzchnie przyczepów dalszych trzech głów mięśnia trójgłowego ramienia (m. triceps brachii), które kończą się wspólnym ścięgnem na tylnej powierzchni wyrostka łokciowego. Guzowatość kości łokciowej (tuberositas ulnae) dla przyczepu mięśnia ramiennego (m. bra- chialis) jest wyraźnie silniej zaznaczona na kości łokciowej prawej.

Kości rąk zachowane niekompletnie: kość księżycowata prawa, kość śródręcza I prawa, kość śródręcza III prawa, kość śródręcza V prawa, kość śródręcza II lewa, kość śródręcza III lewa, dwa paliczki bliższe palców ręki lewej (prawdopodobnie palca III i IV). Zachowane dwa paliczki bliższe ręki lewej wykazują obustronnie, brzegi boczny i brzeg przyśrodkowy, silnie ukształtowane listewki i wyrośla kostne (ryc. 13). 


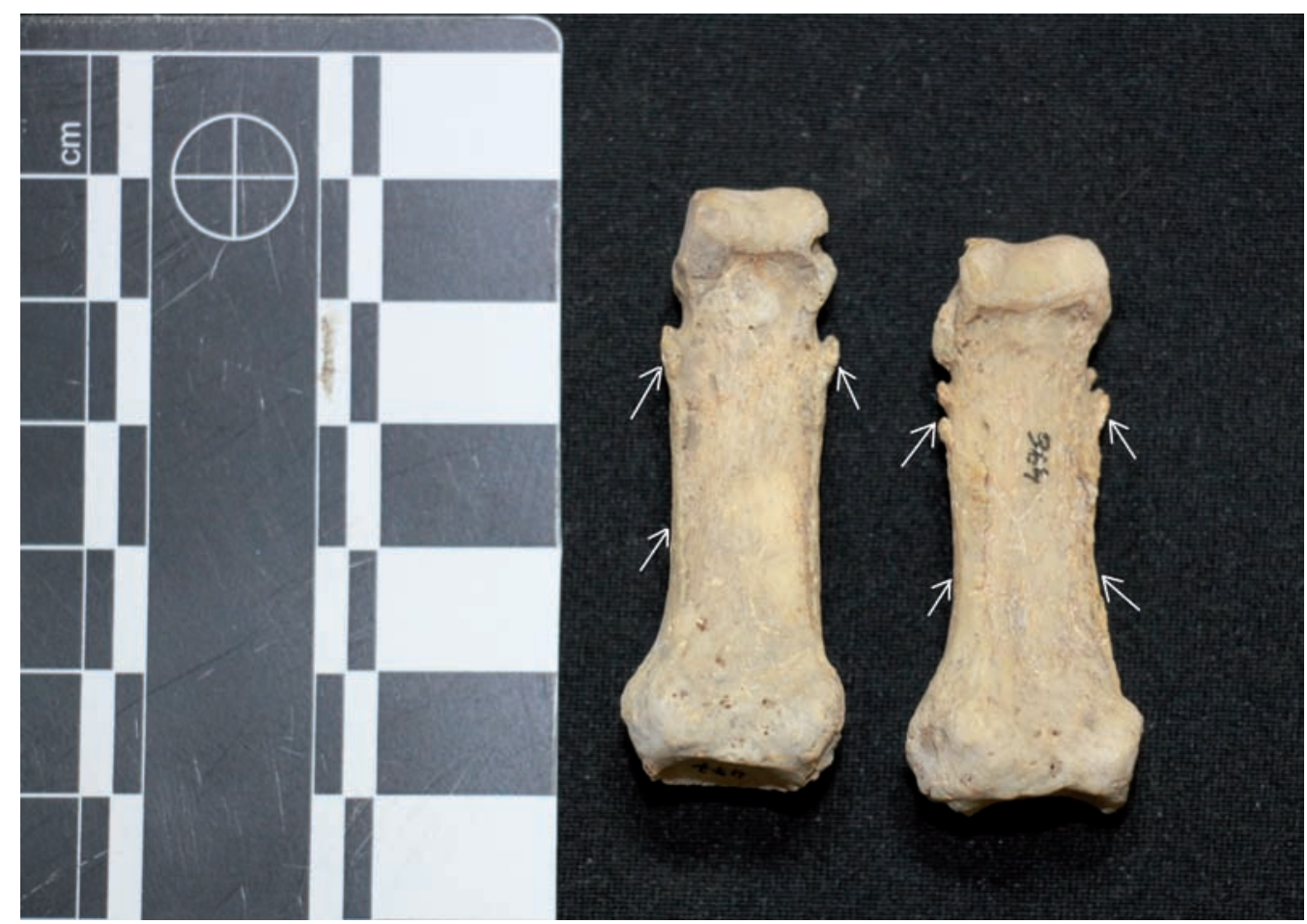

Ryc. 13. Wyznaczniki stresu mięśniowo-szkieletowego (MSM) na paliczkach bliższych ręki lewej, przyczepy mięśnia zginacza powierzchownego palców oznaczono strzałkami. Fot. D. Lorkiewicz-Muszyńska

Fig. 13. Musculoskeletal Stress Markers (MSMs) expression in the left-hand proximal phalanges the attachments of the flexor digitorum superficialis indicated by the arrow. Photo by D. Lorkiewicz-Muszyńska

Kości miedniczne są bardzo kruche i częściowo zachowane. Wcięcie kulszowe większe kości miednicznej prawej jest wąskie i głębokie. Zachowana powierzchnia uchowata kości prawej wykazuje zmiany na poziomie fazy $7 \mathrm{wg}$ Lovejoy i inni (1985). Spojenie zachowane fragmentarycznie, wykazuje wygładzona powierzchnię.

Kości kończyn dolnych są niekompletne. Kości udowe zachowane, lewa jest przełamana post mortem w połowie długości trzonu. Kości piszczelowe zachowane, wykazują ubytki w zakresie końca bliższego kości lewej. Kości strzałkowe uszkodzone. Zachowana jest rzepka lewa. Kości stóp są niekompletnie zachowane: kość piętowa lewa, łódkowata lewa, klinowata przyśrodkowa prawa, jedna uszkodzona kość śródstopia. Kości kończyn dolnych są dużych rozmiarów (tab. 3), masywnej budowy.

Kości kończyn dolnych są masywnej budowy. Kości miedniczne oraz kości kończyn dolnych wykazują zmiany powstałe w wyniku znacznych obciążeń biomechanicznych (MSM). Sklepienia panewek kości biodrowych wykazują ich podwyższenie i zgrubienia kostne. Na tylnej powierzchni trzonów kości udowych obserwuje się obecność hypotrochanteric fossa - podłużny dół ukształtowany bocznie od gu- zowatości pośladkowej. Towarzyszą temu zmiany kształtu trzonu w postaci bocznego ich uwydatnienia na wysokości hypotrochanteric fossa, z jednoczesnym przednio-tylnym przypłaszczeniem trzonu kości na tym odcinku. Na uwagę zasługują silnie ukształtowana guzowatość pośladkowa (tuberositas glutea) będąca miejscem przyczepu mięśnia pośladkowego wielkiego (m. luteus maximus), kresa chropawa (linea aspera) będąca miejscem przyczepu grupy mięśni (mięśnie: przywodziciel wielki, przywodziciel długi, przywodziciel krótki, dwugłowy uda), czy kresa międzykrętarzowa (linea intertrochanterica). W zakresie końców dalszych kości udowych obserwowano silny stopień nasilenia wyznaczników MSN powierzchni nadkłykcia bocznego i nadkłykcia przyśrodkowego. Szczególnie wyraźnie zaznaczone są zmiany na powierzchni przyczepu mięśnia przywodziciela wielkiego (m. adductor magnus) w postaci grzbietu $\mathrm{z}$ wyroślami kostnymi.

Kości piszczelowe wykazują zmiany przeciążeniowe szczególnie w stopniu ukształtowania: guzowatości piszczeli (tuberositas tibiae) stanowiącej przyczep więzadła rzepki i jednocześnie wspólny przyczep końcowy wszystkich głów mięśnia czworogłowego uda (m. quadriceps femoris), kresy mięśnia 
Tabela 3. Grób nr 15. Pomiary elementów szkieletu pozaczaszkowego

Table 3. Grave No. 15. Measurements of the postkranial bones

\begin{tabular}{|ll|c|c|}
\hline \multicolumn{1}{|c|}{ Kość } & Kości strona lewa $(\mathrm{mm})$ & Kości strona prawa $(\mathrm{mm})$ \\
\hline Clavicula & & \\
& pomiar M1 & 165 & 164 \\
& pomiar M4 & 11 & 11 \\
& pomiar M5 & 13 & 13 \\
\hline Humerus & & & 359 \\
& pomiar M1 & 360 & 50 \\
& pomiar M3 & 50 & 65 \\
& pomiar M4 & 66 & 46 \\
& pomiar M10 & 46 & 28 \\
& pomiar M11 & 27 & 284 \\
Radius & & & 17 \\
& pomiar M1 & 286 & 307 \\
& pomiar M4 & 18 & \\
\hline Ulna & pomiar M1 & 309 & 504 \\
& pomiar M1 & & 36 \\
Femur & pomiar M15 & - & 27 \\
& pomiar M16 & 36 & 49 \\
& pomiar M18 & 27 & 49 \\
\hline Tibia & pomiar M1 & 49 & 440 \\
& pomiar M3 & 49 & 81 \\
& pomiar M6 & 439 & 58 \\
\hline
\end{tabular}

płaszczkowatego (linea musculi solei) stanowiącej przyczep części mięśnia płaszczkowatego (m. solei), grzebienia międzykostnego (interosseus membrane). Kresa mięśnia płaszczkowatego jest silniej zaznaczona na kości piszczelowej lewej, gdzie obserwuje się wyrośla kostne. W przypadku rzepki lewej, kości piętowej lewej w miejscach przyczepów obserwuje się ukształtowane bruzdy, wyniosłości i wyrośla kostne.

Wśród szczątków znajduje się częściowo zachowana i skostniała chrząstka tarczowata krtani.

Kości szkieletu pozaczaszkowego są duże i masywne. W zakresie wszystkich elementów szkieletu pozaczaszkowego obserwuje się wyznaczniki stresu mięśniowo-szkieletowego (MSM - muskuloskeletal stress markers). Zmiany wykazują silnie ukształtowane guzki, grzebienie, listewki, zagłębienia, wyrośla kostne, czy wyniosłości o chropowatej powierzchni, które stanowią miejsca przyczepów mięśni i więza- deł. Stopień nasilenia obserwowanych zmian należy uznać za wysoki i jest on wynikiem intensywnej pracy tkanek mięśni za życia osobnika. Ich napinanie, pociąganie, utrzymywania $\mathrm{w}$ stanie napięcia podczas wysiłku fizycznego oddziaływało bezpośrednio na strukturę kości w miejscach przyczepów, jak również na znaczne obszary kości, co skutkowało także zmianami w kształcie kości.

Wyznaczniki stresu mięśniowo-szkieletowego (MSM) wykazują asymetrię. Zmiany są nieco silniej wyrażone na obojczyku lewym, a na kościach kończyny górnej po stronie prawej. W przypadku łopatki obserwuje się także asymetrię co do stopnia nasilenia zmian powierzchni przyczepów części barkowej i grzebieniowej mięśnia naramiennego. W przypadku kości kończyn dolnych stopień wyrażenia MSM jest podobny, choć w przypadku kresy mięśnia płaszczkowatego silniej wyrażona jest ona na kości piszczelowej lewej (ryc. 14). 


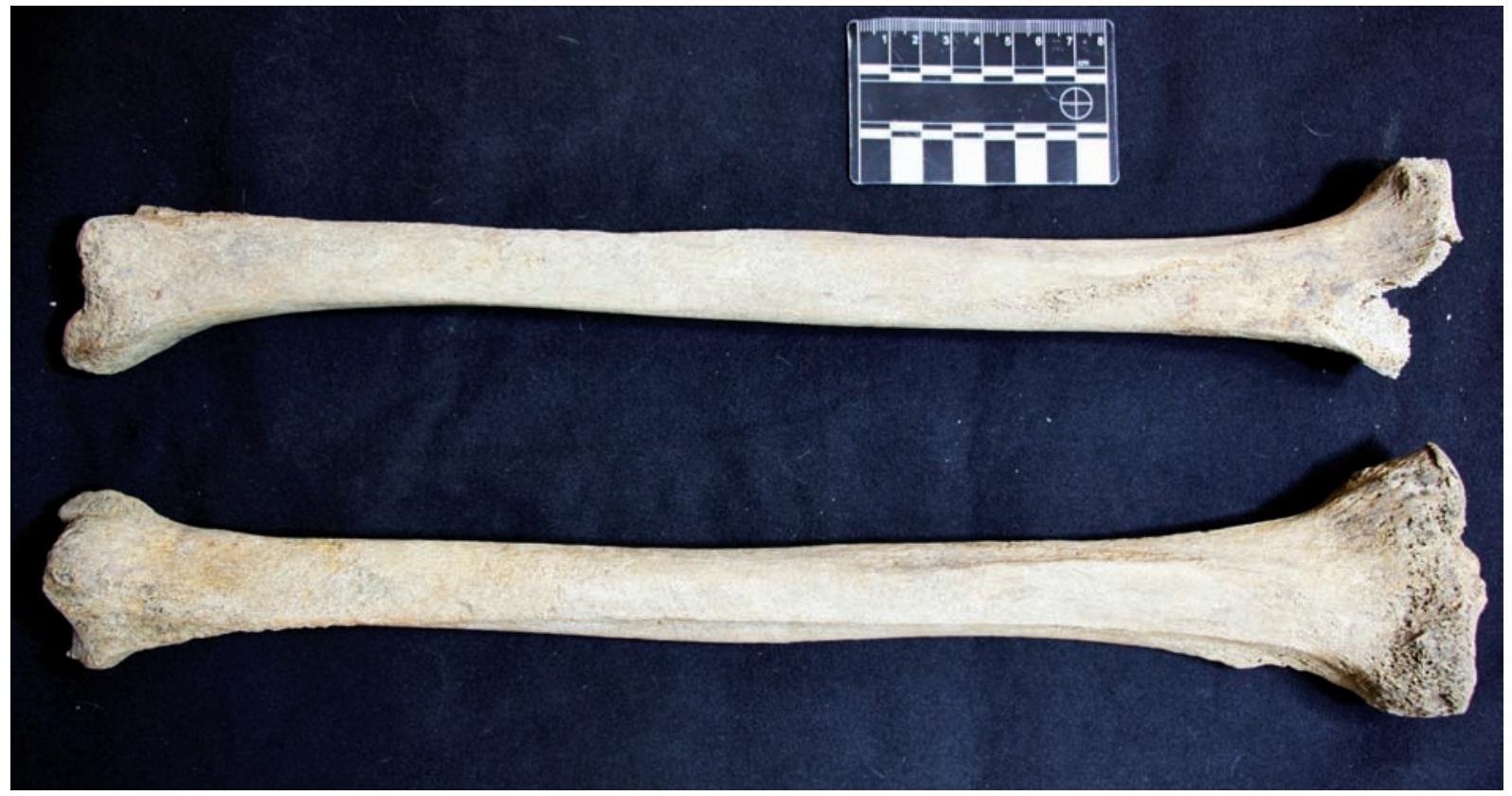

Ryc. 14. Wyznaczniki stresu mięśniowo-szkieletowego (MSM) na kościach piszczelowych - tylna powierzchnia trzonów. Fot. D. Lorkiewicz-Muszyńska

Fig. 14. Musculoskeletal Stress Markers (MSMs) of tibias - posterior surface of shafts.

Photo by D. Lorkiewicz-Muszyńska

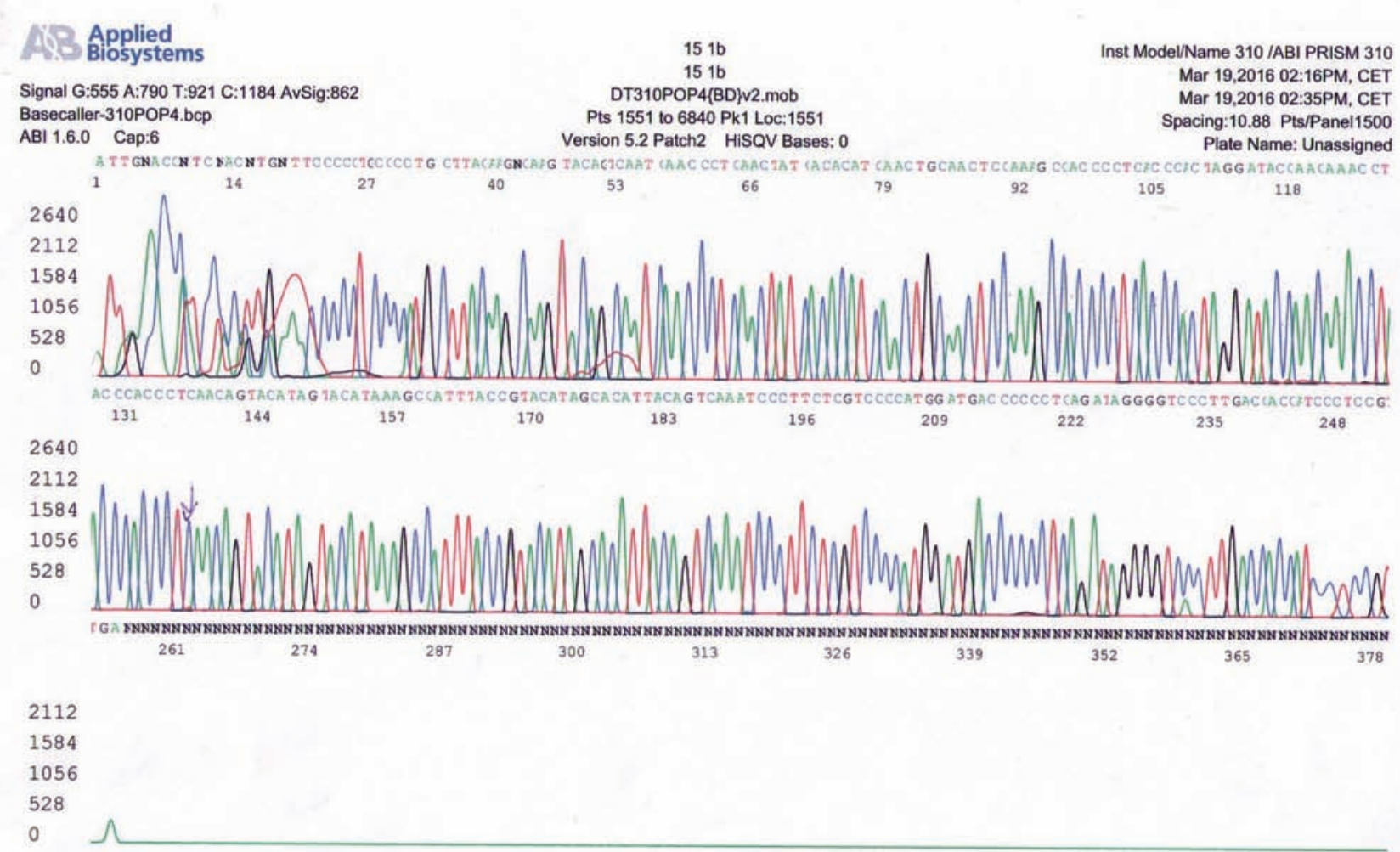

Ryc. 15. Elektroforegram uzyskanego wyniku sekwencjonowania regionu HVSI mitochondrialnego DNA materiału genetycznego szczątków z grobu 15. Fot. M. Abreu-Głowacka

Fig. 15. Electrophoregram presents the result obtained from the sequencing HVSI region of the mitochondrial DNA from the analysis of the remains of grave 15. Photo by M. Abreu-Głowacka 
Szacowania wysokości ciała dokonano na podstawie kości udowej prawej, kości ramiennej prawej, kości promieniowej prawej.

$\mathrm{Na}$ obrazach rentgenowskich kości ramiennych i udowych stwierdza się ubytki istoty gąbczastej w zakresie końców bliższych. W kości ramiennej jama szpikowa znajduje się w pobliżu szyjki anatomicznej, stwierdza się przerzedzenia istoty gąbczastej w guzku większym kości. W przypadku kości udowej, jama szpikowa znajduje się na poziomie krętarza mniejszego.

Uzyskane haplotypy mitochondrialnego DNA (mtDNA) pozwoliły na oszacowanie przynależności osobnika do haplogrupy JT (ryc. 15).

\section{Zmiany patologiczne:}

- schorzenia aparatu żucia: zmiany po toczących się stanach zapalnych związanych z zębami 43 i 44 (żuchwa) i 26 (szczęka), zaawansowane zmiany próchnicowe zęba 26 ;

- dwa bloki kostne odcinka piersiowego kręgosłupa (dwa bloki kostne, każdy powstały ze zrośnięcia dwóch sąsiadujących kręgów) - obserwuje się pełne bloki kostne obejmujące trzony, nasady łuków, stawy międzykręgowe i wyrostki sąsiadujących kręgów. Bloki kostne o prawie całkowitym zatarciu przestrzeni miedzykręgowej, z zachowaniem drożności kanału kręgowego i otworów międzykręgowych. Obserwowane zmiany mają charakter wrodzony;

- zachowane częściowo kręgi lędźwiowe (pięć kręgów) wykazują na brzegach trzonów drobne zmiany o charakterze przeciążeniowym.

Profil osobnika z grobu nr 15:

płeć: męska

wiek (kostny i zębowy): maturus - wiek dojrzały (około 45-55 lat)

wysokość ciała: około $183( \pm 3) \mathrm{cm}$

masa ciala: 71,5 (wg Ruff et al.); 74,6 (wg Grine et al.)

wyznaczniki stresu mięśniowo-szkieletowego (MSM): mocno nasilone w obrębie całego szkieletu

haplogrupa: JT

Kości zwierzęce: dwie kości zwierzęce.

\section{Grób nr 16}

Szczątki z grobu nr 16 wykazują fragmentaryzację czaszki i kości szkieletu pozaczaszkowego. Ponadto cechy kości, kolor, struktura kości, dźwięk jaki słychać przy ich ostukiwaniu, wskazują oddzia- ływanie na nie ognia i wysokiej temperatury. Kości górnej części szkieletu są barwy brunatno-czarnej, na całej ich grubości, co widać w przypadku przełamanych kości. Kości miedniczne, kość krzyżowa i kości kończyn dolnych są barwy brązowej, miejscami brunatnej.

Przed przystąpieniem do analiz dokonano sklejenia pasujących do siebie części poszczególnych kości. Część fragmentów nie była możliwa do sklejenia z uwagi na brakujące części kości i brak ich ciągłości. Niektóre kości są niekompletnie zachowane.

Czaszka zachowana jest niekompletnie i we fragmentach, żuchwa zachowana częściowo. Stwierdza się liczne fragmenty kości części mózgowej w postaci częściowo zachowanych kości ciemieniowych (prawej i lewej), kości skroniowej prawej i lewej, kości czołowej. Wyróżnia się tylne części obu kości ciemieniowych, które sklejono w obrębie tylnej części szwu strzałkowego. Szew strzałkowy w zachowanej części nie wykazuje obliteracji, od strony wewnętrznej brzegi kości tworzące szew są bardziej zaokrąglone. Wyróżnia się częściowo zachowana kość skroniowa lewa wyrostkiem sutkowatym, częścią skalista i wyrostkiem jarzmowym, który wcześniej sklejono. Wyrostek sutkowaty małych rozmiarów, średnio masywnej budowy. Wysokość wrostka sutkowatego wynosi $29 \mathrm{~mm}$. Kość w przedniej jej części jest barwy brunatnej, w 2/3 tylnej części barwy brązowej. Zachowana jest ponadto częściowo kość czołowa obejmująca fragmentarycznie zachowany brzeg nadoczodołowy prawy i fragment łuski kości czołowej z otwartą zatoką czołową. W jednej z komór zatoki widoczny jest zaklinowany ząb przedtrzonowy, który dostał się tam w wyniku procesów depozycyjnych. Zęba nie można usunąć z uwagi na ścisłe zaklinowanie w zatoce czołowej. Zachowany częściowo brzeg nadoczodołowy, z ubytkami na przebiegu brzegu, sprawia wrażenie niezbyt grubego i niezbyt masywnego. Zachowany częściowo łuk brwiowy po stronie prawej lekko zaznaczony. Kości czaszki średnio masywne. Zachowane częściowo brzegi kości tworzące szwy o brzegach pozazębianych. Zachowany fragment żuchwy - zachowana jest gałąź żuchwy lewa z częścią trzonu na odcinku trzech zębów trzonowych. Obserwuje się zarośnięty w pełni zębodół w miejscu brakującego pierwszego lewego zęba trzonowego /36/ - brak zażyciowy, a w miejscu zębów drugiego i trzeciego zęba trzonowego w zębodołach widoczne są jedynie złamane korzenie. Ponadto odłamany jest wyrostek dziobiasty żuchwy. Zachowana część żuchwy jest średnio masywna, rzeźba w okolicy kąta żuchwy jest słabo 
ukształtowana. Z uwagi na stan zachowania czaszki można było wykonać jedynie pomiary wyrostka sutkowatego.

Wśród szczątków wyróżnia jeden luźny ząb trzonowy żuchwy z rozległym ubytkiem próchnicowym na powierzchni żującej zęba, częściowo zachowane dwa zęby przedtrzonowe żuchwy i częściowo zachowany siekacz żuchwy. Zęby są bardzo kruche i spękane.

Szkielet pozaczaszkowy zachowany niekompletnie, kości są zachowane fragmentarycznie, część fragmentów sklejono. Odnotowano 6 częściowo zachowanych kręgów odcinka piersiowego. Kręgi są barwy brunatnoczarnej, miejscami brązowej. Odnotowano 5 kręgów odcinka lędźwiowego, w zachowane częściowo lub z drobnymi ubytkami. Ponadto wyróżnia się kilkanaście oddzielonych fragmentów kręgów - łuki, wyrostki stawowe górne i dolne, wyrostki kolczyste, fragmenty trzonów. Kość krzyżowa i kość guziczka zachowane częściowo, barwy brązowej. W zakresie zachowanych kręgów nie obserwuje się zmian chorobowych.

Z klatki piersiowej zachowało się wiele różnej wielkości fragmentów żeber, które cechują się średnimi rozmiarami i średnią masywnością. $\mathrm{W}$ przypadku zachowanych części obejmujących guzki żeber i głowy żeber obserwuje się zakończone procesy kostnienia. Żebra są barwy brunatno-czarnej.

Zachowane są oba obojczyki, lewy złamany post mortem w połowie trzonu, został sklejony. Oba obojczyki wykazują ubytki w końcach mostowych i barkowych. Kości są średnio masywnej budowy i wysmukłe. Fragmentarycznie zachowane są obie łopatki. Zachowane są panewka stawowa, fragmentarycznie zachowane wyrostki barkowy i kruczy oraz brzeg boczny. Zachowane części kości są średnio masywnej budowy. Obojczyki i łopatki są barwy brunatno-czarnej.

Z kości kończyn górnych zachowane są kości ramienne - po sklejeniu prawa z ubytkami końca bliższego i dalszej części trzonu, lewa z ubytkami i oddzieloną głową - brak ciągłości oddzielonych części kości. Kości średnio masywnej budowy, wysmukłe, cechują się lekko ukształtowaną rzeźbą w miejscach przyczepów mięśniowych. Zachowane są niekompletne kości promieniowe i łokciowe. Kość łokciowa prawa z odłamanym końcem dalszym, kość łokciowa lewa $\mathrm{z}$ odłamaną dalszą częścią na około $1 / 3$ górnej trzonu. Kość promieniowa $\mathrm{z}$ ubytkami w zakresie końca dalszego, kość promieniowa lewa $\mathrm{z}$ odłamaną dalszą częścią na około 1/3 górnej trzonu. Uszkodze- nia kości są pośmiertne. Niekompletnie zachowane są kości rąk. Wyróżniono 7 kości nadgarstka prawego i lewego, w tym część z ubytkami: dwie kości główkowate, lewa kość grochowata, lewa kość łódeczkowata, lewa kość trójgraniasta, lewa czworoboczna większa, lewa czworoboczna mniejsza. W materiale znajdują się ponadto: 4 kości śródręcza, w tym I lewa, trzy pozostałe zachowane częściowo; 6 paliczków bliższych i 5 paliczków środkowych. Kości kończyn górnych są barwy brunatno-czarnej. Kości kończyn górnych wykazują całkowite skostnienie nasad.

W materiale znajdują się częściowo zachowane kości miedniczne (uszkodzone, kości bardzo kruche). Kości są barwy brązowej. Po sklejeniu niektórych fragmentów możliwe było częściowe zrekonstruowanie panewek i wykonanie ich pomiarów (prawa i lewa $53 \mathrm{~mm}$ ). Zachowane kości łonowe wykazują pełne skostnienie. Zachowane fragmenty talerzy kości biodrowych wykazują pełne skostnienie grzebieni kości biodrowych.

Kości udowe zostały częściowo sklejone, lewa wykazuje oddzielone części bez zachowania ciągłości; kości piszczelowe zachowane częściowo, wyróżnia się fragmenty bez zachowania ciągłości; fragmentarycznie zachowane kości strzałkowe; dwie rzepki oraz niekompletnie zachowane kości stóp. Wyróżnia się kości stopy prawej i lewej: częściowo zachowana kość piętowa oraz kość piętowa lewa, kość skokowa prawa i lewa, częściowo zachowaną kość łódkowata prawa i lewa, trzy kości klinowate - pośrednia i boczna prawe oraz przyśrodkowa lewa, kość sześcienna lewa, 4 kości śródstopia (1 prawa i 3 lewe), 2 paliczki dalsze prawe (w tym $1 \mathrm{z}$ nich to paliczek dalszy palucha I). Kości stóp są barwy brązowej, miejscami brunatnej. Kości kończyn dolnych wykazują zakończone procesy kostnienia.

Kości szkieletu pozaczaszkowego są średnich rozmiarów i średnio masywne, wykazują słabo oraz średnio ukształtowaną rzeźbę przyczepów mięśniowych. Nie obserwuje się zmian chorobowych w zakresie zachowanych elementów kostnych, a jedynie w przypadku jednego zęba obserwowano zmiany próchnicowego pochodzenia.

Dokonując analizy pod kątem wyznaczników stresu mięśniowo-szkieletowego (MSM), zaobserwowano, iż kości udowe wykazują lekko nasilone zmiany w wyniku obciążeń biomechanicznych (MSM). Obserwuje się lekko zaznaczoną hypotrochanteric fossa, której towarzyszą delikatnie nasilone zmiany kształtu trzonu w postaci bocznego ich uwydatnienia, z jednoczesnym lekkim przednio-tylnym przypłasz- 
Tabela 4. Grób nr 16. Pomiary elementów szkieletu pozaczaszkowego

Table 4. Grave No. 16. Measurements of the postkranial bones

\begin{tabular}{|c|c|c|}
\hline Kość & $\begin{array}{l}\text { Kości strona lewa } \\
(\mathrm{mm})\end{array}$ & $\begin{array}{l}\text { Kości strona prawa } \\
(\mathrm{mm})\end{array}$ \\
\hline 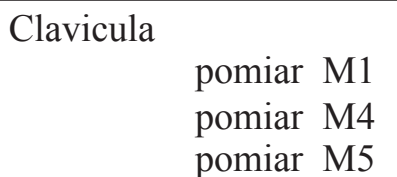 & $\begin{array}{c}- \\
9 \\
11\end{array}$ & $\begin{array}{c}- \\
9 \\
12\end{array}$ \\
\hline 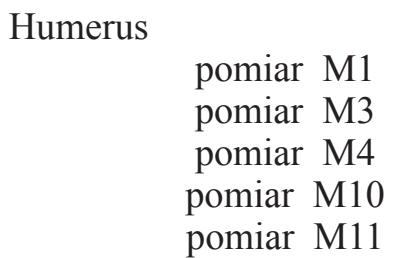 & $\begin{array}{l}- \\
- \\
61 \\
- \\
-\end{array}$ & $\begin{array}{c}313 \\
- \\
61 \\
- \\
-\end{array}$ \\
\hline $\begin{array}{l}\text { Radius } \\
\qquad \begin{array}{l}\text { pomiar M1 } \\
\text { pomiar } \text { M4 }\end{array}\end{array}$ & - & $\begin{array}{l}- \\
14\end{array}$ \\
\hline pomiar M1 & - & - \\
\hline $\begin{array}{l}\text { pomiar M1 } \\
\text { pomiar M15 } \\
\text { pomiar M16 } \\
\text { pomiar M18 } \\
\text { pomiar M19 }\end{array}$ & $\begin{array}{l}- \\
- \\
- \\
-\end{array}$ & $\begin{array}{l}435 \\
31 \\
28 \\
42 \\
42\end{array}$ \\
\hline $\begin{array}{l}\text { pomiar M1 } \\
\text { pomiar M3 } \\
\text { pomiar M6 }\end{array}$ & $\begin{array}{l}- \\
- \\
-\end{array}$ & $\begin{array}{l}- \\
81 \\
58\end{array}$ \\
\hline
\end{tabular}

czeniem trzonu kości na tym odcinku. W zakresie końców dalszych kości udowych obserwowano średnio nasilone zmiany MSN na nadkłykciu bocznym i na nadkłykciu przyśrodkowym.

Szacowania wysokości ciała dokonano na podstawie kości udowej prawej, kości ramiennej prawej.

Profil osobnika z grobu nr 16:

płeć: żeńska?/męska (cechy neutralne, analizy antropologiczne zawężone $\mathrm{z}$ uwagi na rozfragmentowanie i braki części kości) z większym prawdopodobieństwem można przyjąć płeć żeńską, nie można wykluczyć płci męskiej

wiek (kostny i zębowy): adultus (około 25-35 lat)

wysokość ciala: około $163( \pm 2) \mathrm{cm}$ (kobieta)/ $165 \mathrm{~cm}( \pm 2)$ (mężczyzna)

masa ciala: 59,3 (wg McHenry); 58,76 (wg Grine et al.) wyznaczniki stresu mięśniowo-szkieletowego (MSM): nieznacznie nasilone $\mathrm{w}$ obrębie kości kończyn dolnych i górnych haplogrupa: (degradacja DNA)

\section{PODSUMOWANIE}

Interdyscyplinarne badania kostnych szczątków ludzkich, pomimo fragmentarycznego stanu zachowania materiałów kostnych z grobu 13 i 14, pozwoliły na ustalenie szeregu istotnych informacji dotyczących osób zmarłych. Niektóre fragmenty kostne i zęby osobnika z grobu nr 14 wykazują zmiany powstałe wyniku oddziaływania na nie ognia i wysokich temperatur. Drobne elementy kostne oraz zęby są bardzo kruche i podatne na dalsze uszkodzenia. Wśród szczątków z grobu nr 14 znaleziono nieliczne fragmenty kostne 
pochodzące z czaszki i szkieletu pozaczaszkowego (dwa fragmenty kości sklepienia czaszki, paliczek dalszy) innej osoby. Istnieje prawdopodobieństwo, że kości mogą należeć do osobnika z grobu 16, który znajdował się w bezpośredniej okolicy.

Analizowane szczątki ludzkie należały do co najmniej czterech osobników, w tym dwóch dorosłych - jednego osobnika płci męskiej w wieku maturus (grób nr 15), osobnika w wieku adultus o płci niemożliwej do jednoznacznego ustalenia (z większy prawdopodobieństwem przyjęto płeć żeńską) oraz dwóch osobników dziecięcych - w wieku infans I i infans I/ infansII. W przypadku jednego z osobników dziecięcych, z grobu nr 13, wstępnie otrzymane wyniki badań genetycznych wskazują na płeć żeńską dziecka. W przypadku drugiego osobnika dziecięcego z grobu nr 14, z uwagi na stan szczątków, zmiany pod wpływem działania płomieni i wysokiej temperatury i znaczną degradację DNA, płci nie udało się ustalić. Badania w tym zakresie są kontynuowane.

W przypadku pochowanego w grobie nr 15 dorosłego osobnika płci męskiej wysokość ciała oszacowano na około $183 \mathrm{~cm}$, wiek w chwili zgonu oszacowano w zakresie 45-55 lat. Wykonane zdjęcia rentgenowskie, a następnie obserwacje zdjęć rtg pozwoliły na ocenę struktur kostnych i patologii kostnych niewidocznych w badaniach makroskopowych (Murphy et al. 1980; Kociemba 2015; Lorkiewicz-Muszyńska et al. 2016). Podczas badań szczątków osobnika z grobu nr 15 zaobserwowano patologie wrodzone w postaci dwóch pełnych bloków kostnych w odcinku piersiowym kręgosłupa, obejmujących trzony, nasady łuków, stawy międzykręgowe i wyrostki. Bloki kostne o prawie całkowitym zatarciu przestrzeni miedzykręgowej, z zachowaniem drożności kanału kręgowego i otworów międzykręgowych (ryc. 10: A-C). Na kręgach lędźwiowych zaobserwowano zmiany przeciążeniowe na obwodach trzonów kręgów.

Stwierdzono również schorzenia aparatu żucia w postaci zmian po toczących się stanach zapalnych związanych z zębami 43 i 44 (żuchwa) i 26 (szczęka), zaawansowane zmiany chorobowe zęba 26 o charakterze próchnicowym. Próchnica w materiałach archeologicznych nie jest częstym zjawiskiem i jej obecność jest dużo rzadsza, niż u ludzi żyjących współcześnie (Tomczyk et al. 2014; Glapiński et al. 2015, Przystańska et al. 2017). Występowanie próchnicy ma związek z dietą, w szczególności w przypadku populacji pradziejowych ze znacząco mniejszym spożyciem cukrów, szczególnie prostych, które stanowią główną pożywkę dla bakterii (Tomczyk et al.
2014; Glapiński et al. 2015; Przystańska et al. 2017). W przypadku występującej próchnicy obserwuje się zazwyczaj znaczne zniszczenie struktury zęba oraz obecność zmian zapalnych w obrębie kości, co świadczy o długotrwałości tego procesu (Glapiński et al. 2015; Przystańska et al. 2017). Higiena jamy ustnej w dawnych czasach stała niewątpliwie na niższym poziomie, o czym świadczą często obserwowane złogi kamienia nazębnego u osobników z populacji pradziejowych. U osobnika z grobu nr 15 także obserwuje się obecność kamienia nazębnego, zarówno na powierzchniach policzkowych, jak i językowych zachowanych zębów przedtrzonowych i trzonowych.

W przypadku zachowanych zębów u osobnika z grobu nr 15 zaobserwowano uderzające podobieństwo w starciu zębów jak u innych osobników z cmentarzyska w Rogalinie (Glapiński et al. 2015; Przystańska et al. 2017). Zachowane zęby, tj. kieł, a także przedtrzonowce i trzonowce są mocno starte, z obnażonymi pasmami i wyspami zębiny na brzegach siecznych i powierzchniach żujących. Stosowanie diety bogatej w produkty twarde i nieoczyszczone, zawierające elementy ścierne, skutkuje znacznym zużyciem zębów. Początkowo zęby przedtrzonowe i trzonowe posiadają zaokrąglone guzki żujące umożliwiające przeżuwanie, kły natomiast brzegi sieczne umożliwiające przytrzymywanie i rozrywanie pokarmów. Z upływem czasu te struktury ulegają starciu, wygładzeniu i wypłaszczeniu, co wykorzystywane jest jako jedna $\mathrm{z}$ cech pomocnych przy szacowaniu wieku (Glapiński et al. 2015; Przystańska et al. 2017). W celu szacowania wieku biologicznego wykorzystano także kryterium wieku zębowego u osobników dziecięcych (Haavikko 1970). Rozwój zębów, zarówno mlecznych, jak i stałych, charakteryzują dwa główne procesy: formowanie korony i korzenia oraz wyrzynanie zęba (Haavikko 1970; Przystańska et al. 2015 i 2017). Kształtowanie się i wyrzynanie zębów przebiega w kilku stadiach, które są uporządkowane i zachodzą w określonej kolejności i w określonym przedziale czasowym, a im młodszy osobnik, tym zmiany są bardziej dynamiczne (Demirjian et al. 1973; Lorkiewicz et al. 2015; Przystańska et al. 2015 i 2017).

Uwzględniając cechy budowy kości czaszki i szkieletu pozaczaszkowego osobnika z grobu nr 15, geometrię kości kończyn górnych i kończyn dolnych, nasilone wyznaczniki stresu mięśniowoszkieletowego (MSM) w obrębie całego szkieletu, można wnioskować, iż mężczyzna podczas swego życia wykazywał wysoką aktywność fizyczną i wy- 
konywał ciężką, obciążającą układ kostny i mięśniowy pracę. Regularnie i ze znaczną intensywnością wykonywane i powtarzane przez wiele lat życia te same czynności, wymagające znacznego wysiłku fizycznego, wpłynęły istotnie na kształt i stan kości tego osobnika. Mężczyzna ten niewątpliwie wykonywał za życia bardzo ciężkie prace fizyczne, dźwigał i przenosił ciężkie przedmioty (Hawkey 1998; Peterson 1998; Mariotti et al. 2007; Iwanek et al. 2010). Zespół wyznaczników stresu mięśniowo-szkieletowego kości obręczy barkowej, kości kończyn górnych i kości kończyn dolnych oraz cechy panewek stawów biodrowych, wskazywać mogą również na częstą i intensywną jazdę konną, a także możliwość strzelania z łuku (Foster et al. 2012; Berthom et al. 2018). Na uwagę zasługuje tu asymetria intensywności zaznaczenia zmian analizowanych powierzchni przyczepów mięśni i ich poszczególnych części w zestawieniu z ich czynnościami. Szczególnie istotna wydaje się tu asymetria stopnia zmian powierzchni przyczepów początkowych poszczególnych części mięśnia naramiennego w zestawieniu z ich czynnościami. Silniej wyrażone zmiany powierzchni przyczepów części obojczykowej i grzebieniowej (przywodzenie, rotacja do wewnątrz i na zewnątrz) mięśnia naramiennego na obojczyku lewym i wyrostku barkowym łopatki lewej oraz silniej wyrażone zmiany powierzchni przyczepów części barkowej (odwodzenie do poziomu) tego mięśnia na wyrostku barkowym łopatki prawej wskazują na zróżnicowane czynności kończyn górnych o charakterze powtarzalnym, skutkujących powstaniem opisanej asymetrii. Tym zmianom towarzyszą wyraźnie zaznaczone zmiany powierzchni przyczepów mięśni (listewki kostne, wyniosłości) na zachowanych kościach ręki - kości śródręcza i kości palców. Uwzględniając asymetrie stopnia nasilenia zmian powierzchni przyczepów mięśni kości ramiennych i kości przedramienia strony prawej i lewej, można $\mathrm{z}$ większym prawdopodobieństwem wnioskować, iż wiodącą u osobnika $\mathrm{z}$ grobu nr 15 była kończyna górna prawa.

Badania genetyczne szczątków z grobów nr 13, 15 i 16 ze względu na degradację DNA nie dostarczyły jednoznacznych wyników dotyczących płci badanych osobników. Wstępne badania szczątków z grobu 13 w zakresie markera amelogeniny, który dostarcza in- formacji na temat płci genetycznej, wskazują na płeć żeńską. Kopalny DNA to materiał genetyczny, który można uzyskać ze szczątków różnych organizmów. Zwykle występuje on w małych ilościach. W związku z tym jest bardzo podatny na mutacje i kontaminacje (zanieczyszczenia) z egzogennym „współczesnym” DNA (Paabo et al. 2004).

Stopień degradacji DNA uzyskanego z badanych kości jest tak wysoki, że pozytywny wynik uzyskano tylko podczas analizy mitochondrialnego DNA grobów 13 i 15. Uzyskane haplotypy mtDNA wskazują, że badane szczątki należały do haplogrupy JT. Haplogrupa JT najczęściej występuje w Zachodniej Euroazji. Haplogrupa ta pochodzi z pre-haplogrupy JT, która prawdopodobnie powstała 50000 lat temu i charakteryzuje się markerami genetycznymi takich jak: 11251, 15452A oraz 16126 (Oven et al. 2008). Potomkowie haplogrupy JT rozprzestrzenieni są po całej zachodniej Euroazji, w szczególności na Bliskim Wschodzie, ale również w Europie, w Zachodniej Syberii, w Centralnej Azji oraz w Afryce Północnej. Jednocześnie, doniesienia naukowe wskazują na występowanie haplogrupy JT pośród starożytnych Etrusków, którzy żyli w Toskanii we Włoszech (Achilli et al. 2007).

Należy wziąć jednak pod uwagę, że badaniu został poddany tylko mały region mtDNA (HVSI oraz HVSII). Aby potwierdzić powyższe wyniki, należałoby rozszerzyć analizę mtDNA ze względu na rodzaj materiału badanego, tj. kopalny DNA, korzystna wydaje się być sugestia poszerzenia badania poza regiony hiperzmienne, nawet o regiony kodujące, czy pełen genom mitochondrialny, w celu sklasyfikowania jednostki do bardziej ograniczonej subhaplogrupy oraz uzyskania indywidualnych cech osobniczych (Goodwin et al. 2011).

Dodatkowo korzystano z pionierskiej metody, stosowanej $\mathrm{w}$ genetyce sądowej, którą jest sekwencjonowanie nowej generacji. Dostarcza ona nieograniczonej ilości informacji genetycznej, pozwalając na oznaczenie blisko 100 genotypów. Natomiast do ww. metody wymagana jest duża ilość DNA (około $0,2 \mathrm{ng}$ ), a przede wszystkim musi on być wysoko jakościowym materiałem genetycznym, tj. o niskim stopniu degradacji. Badania genetyczne są kontynuowane. 


\section{BIBLIOGRAFIA}

Abreu-Głowacka M. (2015). Badania genetyczne - odkrywanie tajemnic grobów kultury strzyżowskiej. W: A. Hyrchała, B. Bartecki (red.), Wojownik i księżniczka - archeologia - medycyna sądowa - sztuka (170181). Hrubieszów: Muzeum im. ks. St. Staszica.

Achilli A. et al. (2007). Mitocondrial DNA variation of modern Tuscans supports the Near Eastern Origin of Etruscans. American Journal of Human Genetics: April 2007.

Acsadi G., Nemeskeri I. (1970). History of Human Life Span and Mortality. Budapest.

Auerbach B.M., Ruff Ch.B. (2004). Human Body Mass Estimation: A Comparison of "Morphometric" and "Mechanical" Methods. American Journal of Physical Anthropology, 125(4), 331-342.

Berthom W., Tihanyi B., Kis L., Révész L., Coqueugniot H., Dutour D., Pálfi G. (2018). Horse riding and the shape of the acetabulum: Insights from the bioarchaeological analysis of early Hungarian mounted archers (10th century). International Journal of Osteoarcheology, 29(1), 117-126.

Bochenek A., Reicher M. (2019). Anatomia człowieka 1. Warszawa: PZWL.

Buikstra J.E., Ubelaker D.H. (1994). Standards for Data Colllection from Human Skeletal Remains: Proceedings of a seminar at the Field Museum of Natural History. Arcansas Archaeological Survey Research Series. New York.

Demirjian A., Goldstein H., Tanner J.M. (1973). A new system of dental age assessment. Human Biology, 45, 221-227.

Foster A., Buckley H.R., Tayles N. (2012). Using Enthesis Robusticity to Infer Activity in the Past: A Review. Journal of Archaeological Method and Theory, 21(3), 1-23. doi: 10.1007/s10816-012-9156-1.

Glapiński M., Przystańska A., Kulczyk T. (2015). Zabawa w Puzzle i rozwiązywanie zagadek. W: A. Hyrchała, B. Bartecki (red.), Wojownik i księżniczka - archeologia - medycyna sądowa - sztuka (154-161). Hrubieszów: Muzeum im. ks. St. Staszica.

Goodwin W., Linacre A., Hadi S. (2011). Lineage markers. An Introduction to Forensic Genetics. John Wiley \& Sons Ltd., 155-169.

Grine F.E., Jungers W.L., Tobias P.V., Pearson O.M. (1995). Fossil Homo femur from Berg Aukas, northern Namibia. American Journal of Physical Anthropolgy, 97(2), 151-185.
Haavikko K. (1970). The formation and the alveolar and clinical eruption of the permanent teeth. Anorthopantomographic study. Suomen Hammaslaakariseuran Toimituksia, 66(3), 103-170.

Hawkey D.E. (1998). Disability, Compassion and the Skeletal Record. International Journal of Osteoarchaeology, 8, 326-340.

Hawkey D.E., Merbs C.F. (1995). Activity-Inducet Musculoskeletal Stress Markers (MSM) and Subsistance Strategy Changes among Ancient Hudson Bay Eskimos. International Journal of Osteoarchaeology, 5, 324-338.

Hyrchała A. (2015). Wojownik i Księżniczka z Rogalina - nowy rozdział w dziejach badań nad kulturą strzyżowską. W: A. Hyrchała, B. Bartecki (red.), Wojownik $i$ księżniczka - archeologia - medycyna sadowa - sztuka (52-79). Hrubieszów: Muzeum im. ks. St. Staszica.

Hyrchała A. (2021). Igranie z ogniem - rytuały pogrzebowe kultury strzyżowskiej na przykładzie wybranych pochowków z cmentarzyska w Rogalinie, w tym tomie.

Iwanek B., Piontek J., Nowak O. (2010). Analiza antropologiczna szkieletu z Bruszczewa. W: J. Müller et al. (red.), Wykopaliska w Bruszczewie II. SAO / SPEŚ 6 (730-753). Bonn.

Khudaverdyan A.Y., Khachatryan H.H., Eganyan L.G. (2017). The human skeleton from the late iron age burial of Shirakavan (Armenia): a case study. Bulletin of the Intrernational Association for Paleodont, 11(2), 51-61.

Kociemba W. (2015). Techniki obrazowania w radiologii, rola tomografii komputerowej i rezonansu magnetycznego w archeologii. W: A. Hyrchała, B. Bartecki (red.), Wojownik i księzniczka - archeologia - medycyna sądowa - sztuka (124-129). Hrubieszów: Muzeum im. ks. St. Staszica.

Lorkiewicz-Muszyńska D. (2015). Czaszka prawdę ci powie. W: A. Hyrchała, B. Bartecki (red.), Wojownik i księżniczka - archeologia - medycyna sąowa sztuka (140-145). Hrubieszów: Muzeum im. ks. St. Staszica.

Lorkiewicz-Muszyńska D., Kociemba W., Rewekant A. (2015). Charakterystyka szczątków kostnych z cmentarzyska w Rogalinie. W: A. Hyrchała, B. Bartecki (red.), Wojownik i księzniczka - archeologia - medycyna sąowa - sztuka (130-139). Hrubieszów: Muzeum im. ks. St. Staszica. 
Lorkiewicz-Muszyńska D., Kociemba W., Rychlik M.(2016). Badania identyfikacyjne szczątków. W: T. Dzieńkowski (red.), Horodysko. Od epoki kamienia do wczesnego średniowiecza. Badania 2005-2006 (309-322). Lublin.

Lorkiewicz-Muszyńska D., Przystańska A., Kulczyk T., Hyrchała A., Bartecki B., Kociemba W., Glapiński M., Łabęcka M., Świderski P. (2015). Wykorzystanie zdjęć rentgenowskich do oceny wieku zębowego dla celów medyczno-sądowych. Arch Med Sąd Kryminol., 65(1), 1-16.

Lovejoy C.O. (1985). Dental Wear in the Libben Population: Its Functional Pattern and Role in the Determination of Adult Skeletal Age at Death. American Journal of Physical Antropology, 68(1), 47-56. doi: 10.1002/ ajpa.1330680105.

Lovejoy C.O., Meindl R.S., Pryzbeck T.R., Mensforth R.P. (1985). Chronological metamorphosis of the auricular surface of the ilium: a new method for the determination of adult skeletal age at death. American Journal of Physical Antropology, 68(1), 15-28. doi: 10.1002/ ajpa.1330680103.

Malinowski A., Strzałko J. (1985). Antropologia. Warszawa.

Malinowski A., Wolański N. (1988). Metody badań w biologii Człowieka: wybór metod antropologicznych. Warszawa.

Mariotti V., Facchini F., Giovanna B.M. (2007). The study of entheses: proposal of a standardised scoring method for twenty-three entheses of the postcranial skeleton. Collegium Antropologicum, 31(1), 291-313.

Martin R., Saller K. (1957). Lehrbuch der Anthropologie. Stuttgart.

Murphy W.A., Spruill F.G., Gantner G.E. (1980). Radiologic Identification of Unknown Human Remains. Journal of Forensic Sciences, 25(4), 727-735.

Myszka A. 2007. Rekonstrukcja budowy somatycznej człowieka na podstawie wybranych cech szkieletu. Seria Antropologia nr 24. Poznań: Wydawniwctwo UAM.

Paabo S., Poinar, H., Serre D., Jaenicke-Despres V., Hebler J., Rohland N., Kuch M., Krause J., Vigilant L., Hofreiter M. (2004). Genetic analyses from ancient DNA. Annual Review of Genetics, 38, 645-679. doi: 10.1146/annurev.genet.37.110801.143214.

Peterson J. (1998). The Natufian hunting conundrum: spears, atlatls, or bows? Musculoskeletal and armature evidence. International Journal of Osteoarcheology, 8(5), 378-389.

Przystańska A., Kulczyk T., Glapiński M. (2015). Ile masz lat. W: A. Hyrchała, B. Bartecki (red.), Wojownik i księżniczka - archeologia - medycyna sądowa sztuka (162-167). Hrubieszów: Muzeum im. ks. St. Staszica.

Przystańska A., Lorkiewicz-Muszyńska D., Abreu-Głowacka M., Glapiński M., Sroka A., Rewekant A., Hyrchała A., Bartecki B., Żaba Cz., Kulczyk T. (2017). Analysis of human dentition from Early Bronze Age: 4000-year-old puzzle. Odontology, 105(1), 13-22. doi: 10.1007/s10266-015-0220-7.

Ruff C.B., Scott W.W., Liu A.Y.C. (1991). Articular and diaphyseal remodeling of the proximal femur with changes in body mass in adults. American Journal of Physical Anthropolgy, 86(3), 397-413. doi: 10.1002/ajpa.1330860306.

Smith B.G., Knight J.K. (1984). An index for measuring the wear of teeth. British Dental Journal, 156(12), 435438. doi: 10.1038/sj.bdj.4805394.

Todd T.W. (1920). Age changes in the pubic bone: I. The white male pubis. American Journal of Physical Anthropology, 57(3), 467-470.

Tomczyk J., Komarnitki J., Zalewska M., Wiśniewska E., Szopiński K., Olczak-Kowalczyk D. (2014). The Prevalence of Pulp Stones in Historical Populations From the Middle Euphrates Valley (Syria). American Journal of Physical Anthropology, 153, 103-115.

Trotter M., Gleser G.C. (1952). Estimation of stature from long bones of American Whites and Negroes. American Journal of Physical Anthropology, 10(4), 463-514. doi: 10.1002/ajpa.1330100407

Turp J.C., Kurt W.A. (1995). Designating teeth: The advantages of the FDI's two-digit system. Quintessence International, 26(7), 501-504.

Ubelaker D.H. (1978). Human skeletal remains: excavation, analysis, interpretation. Aldine Manuals on Archeology, Chicago.

White T.D., Folkerns P.A. (2005). The human Bone Manual. New York.

Van Oven M., Kayser M. (2008). Updated comprehensive phylogenetic tree of global human mitochondrial DNA variation. Human Mutation 30(2): E386-E394. PMID 18853457. doi: 10.1002/humu.20921. 


\title{
DOROTA LORKIEWICZ-MUSZYŃSKA, MONICA ABREU-GŁOWACKA, WOJCIECH KOCIEMBA, MARIUSZ GLAPIŃSKI, ELIZA MICHALAK, MARZANNA CIESIELKA, ANNA HYRCHAŁA
}

\author{
HUMAN SKELETAL REMAINS FROM FOUR GRAVES \\ OF STRZYŻÓW CULTURE EXCAVATED IN 2015-2016 AT SITE 15 \\ IN ROGALIN, POLAND STUDIED IN INTERDISCIPLINARY RESEARCH
}

\section{SUMMARY}

Introduction: In 2008 a burial site was discovered in Rogalin (eastern Poland). Interdisciplinary investigations were carried out and it was concluded that the site was a unique example of Strzyżów culture, an agricultural culture found in eastern Poland and western Ukraine, dated to the Early Bronze Age (2000/1950-1600 BC). Strzyżów culture spread over the area from the eastern part of Lublin Upland (area between the upper Wieprz river and Bug river) to the area of south-western Volhynia crossing the Horyn river in present-day Ukraine. The highest density of its sites is in the territory of Horodło Plateau and near the town of Hrubieszów. Sixteen graves were discovered between 2009 and 2016.

Aim: The aim of the study was to conduct analysis of skeletal remains from four burial graves - no. 13, 14, 15, and 16 excavated in 2015 and 2016. Research was based on macroscopic, stereomicroscopic analysis, X-ray and CT examinations.

Material and methods: Interdisciplinary investigations of excavated skeletal remains from burials no. 13, 14, 15, and 16 were carried out. The studies corroborate the state of knowledge in anthropological, radiological, odontological and genetical investigations. The studies were based on visual inspection, stereomicroscopic investigation, and classic radiology in order to determine the biological profile and status of skeletons, as well as to diagnose any bone pathologies and abnormalities.

Results: Interdisciplinary research of the human remains excavated in 2015 and 2016 from the four graves no. $13,14,15$, and 16 allowed the researchers to determine a set of significant information about the deceased. Only the remains from grave no. 15 were preserved in good condition, the others were fragmented. Additionally, the remains from graves no. 14 and 16 showed changes caused by exposure to high temperatures and fire. The conducted studies proved that the bone remains belonged to at least four individuals, including two adults (aged adultus and maturus), and two children, one aged infans $I$ and the other one in the age category infans I/infans II. In grave no. 14 further small fragments of another individual were found (fragments of skull bones and one distal phalange). Bone fragments discovered in grave no. 14 showed similarity in color, thickness, and massiveness to the remains of the individual from grave no. 16. The stature of an individual from grave no. 15 was estimated on the basis of measurement of long bones. Some pathologies and developmental abnormalities in the case of individual from grave no. 15 were found. Among the pathologies were: degenerative changes of the lumbar vertebrae, ossification of the thoracic vertebrae, and block vertebrae (Fig. $10 \mathrm{~A}, \mathrm{~B}, \mathrm{C}$ ).

The postcranial skeleton (particularly the shoulder girdle and bones of the upper limbs, pelvis with lower limbs) was examined in the aspect of musculoskeletal stress markers (MSM). Musculoskeletal stress markers are bone changes manifested as increased complexity of the surfaces of muscles attachment sites (Myszka 2007). The degree of intensity of the observed changes should be considered as high and as the result of physical activity and intense work of the muscle tissues during the life of the individual. Such intense muscular effort over lifespan had impact on the bone structure in the places of attachments, as well as on significant areas of the bones, which resulted in their characteristic shape (geometry), too. The type and intensity of the observed changes indicate that the subject showed considerable physical activity during his lifetime, including the ability to frequently travel on horseback and possibly practice archery. The asymmetry in the degree of expression of the musculoskeletal stress markers was observed between the right and left bones of lower and upper limbs. Right side dominance in the MSM size of upper limbs was found. In the area of the preserved teeth, significant wear of the tooth crowns was found, similar to other individuals from burial site in Rogalin. The importance of dental age estimation was confirmed in the children from grave no. 13 (infans I) 
and no. 14 (infans I/infans II). Diseases of the masticatory apparatus were also observed in the form of changes following the ongoing inflammation related to teeth 43,44 , and 26, and advanced carious changes of tooth 26 (Fig. $5 \mathrm{~A}$, $\mathrm{B} ; 6 \mathrm{~A}, \mathrm{~B})$. The bone loss and opened maxillary sinus at the level of the root of tooth 26 was disclosed. Signs of dental caries in tooth 26 were observed (Fig. 5 B).

The DNA gave more information about the sex of children from grave no. 13 (female) and ancestry of the individuals from graves no. 13 and 15 (haplogroup JT). As regards the second infant individual from grave no. 14 and the adult from grave no. 16, due to the state of the remains, changes caused by exposure to high temperatures, and significant DNA degeneration, it was not possible to determine either the sex or haplogroup of the individuals.

Conclusion: More detailed results are obtained when archeological research utilizes modern medical technology and techniques to evaluate specimens. Research based on macroscopic, stereomicroscopic analysis, X-ray and CT examinations allow to observe the surface and look inside each anatomic structure.

The paleodontological analysis of the Strzyżów culture population from the burial site in Rogalin was significantly extended and enriched using radiological methods (Kociemba 2015; Lorkiewicz-Muszyńska 2015; LorkiewiczMuszyńska et al. 2015; Przystańska 2015 and 2017). The usefulness of X-ray and CT examination in diagnosis of bones and teeth-related diseases was proven in a number of studies.

Caries causes extensive damage to the tooth structure. Inflammation within the bone and alveolar socket sustains the process and, in highly progressed cases, infection spreads from the tooth to the surrounding soft tissues and organs (Przystańska et al. 2017). A carious lesion was observed to have extended to the pulp in the case of the individual from grave No. 15. The periapical disease in the same individual was probably a consequence of inflammation and an infective reaction. Severe infection or inflammation, after extreme wear or destructive cavities, may lead to loss of the tooth (Glapiński et al. 2015; Przystańska et al. 2017). X-ray and CT are very useful methods for dental age assessment, too. Age assessment should be a comprehensive process taking into account as many determinants and characteristics as possible. One of the criteria playing crucial role in age estimation is dental age. Dental age can be estimated with high degree of accuracy in children and adolescents because of changes occurring dynamically and regularly (Haavikko 1973; Demirjian et al. 1973; Lorkiewicz-Muszyńska et al. 2015). Methods based on tooth wear pattern are relatively easy but not accurate, however, when used with other age assessment techniques they can be a useful indicator of age. Methods based on teeth development, tooth wear pattern, the degree of development of different features of the skeletal system, and the stage of progression of degenerative changes - these help to estimate biological age.

Examination of the methods for reconstructing biological profile - the sex, biological age, body height, body weight, and other significant characteristics of the human somatic structure, is one of the principal focuses of research during paleodontological investigations of human remains from archeological sites. Modern medical technology and techniques used during investigations, along with cooperation between specialists in anthropology, odontology, radiology, and genetics makes it possible to obtain significant information about people from the past.

Adresy Autorów:

Dr n. biol. Dorota Lorkiewicz-Muszyńska

Katedra i Zakład Medycyny Sądowej Uniwersytetu Medycznego

im. Karola Marcinkowskiego w Poznaniu

ul. Święcickiego 6; 60-789 Poznań

e-mail: dlorkiew@ump.edu.pl

(iD https://orcid.org/0000-0001-8868-8812 
Dr n. biol. Monica Abreu-Głowacka

Katedra i Zakład Medycyny Sądowej Uniwersytetu Medycznego

im. Karola Marcinkowskiego w Poznaniu

ul. Święcickiego 6; 60-789 Poznań

e-mail: abreuglowacka@ump.edu.pl

(iD https://orcid.org/0000-0002-3090-4786

Dr n. med. Wojciech Kociemba

Oddział Neurochirurgii, Wielospecjalistyczny Szpital Miejski

im. Józefa Strusia w Poznaniu

ul. Szwajcarska 3; 61-285 Poznań

e-mail:wkociemba@wp.pl

(iD) https://orcid.org/0000-0002-3706-4054

Dr n. med. Mariusz Glapiński

Katedra i Zakład Medycyny Sądowej Uniwersytetu Medycznego

im. Karola Marcinkowskiego w Poznaniu

ul. Święcickiego 6; 60-789 Poznań

e-mail: mariusz.glapinski@gmail.com

(iD https://orcid.org/0000-0003-1682-8921

Mgr inż. biotech. Eliza Michalak

Katedra i Zakład Medycyny Sądowej Uniwersytetu Medycznego

im. Karola Marcinkowskiego w Poznaniu

ul. Święcickiego 6; 60-789 Poznań

e-mail: emichalak@ump.edu.pl

iD https://orcid.org/0000-0001-8155-4475

Dr n. med. Marzanna Ciesielka

Katedra i Zakład Medycyny Sądowej Uniwersytetu Medycznego w Lublinie ul. dr Kazimierza Jaczewskiego 8; 20-400 Lublin

e-mail: marzannaciesielka@umlub.pl

(iD https://orcid.org/0000-0002-2685-8764

Mgr Anna Hyrchała

Dział Archeologiczny Muzeum im. ks. St. Staszica w Hrubieszowie

ul. 3-go Maja 11; 22-500 Hrubieszów

e-mail: ahyrchala@gmail.com

(iD https://orcid.org/0000-0001-8749-1583 
